\title{
WestVirginiaUniversity
}

THE RESEARCH REPOSITORY @ WVU

Graduate Theses, Dissertations, and Problem Reports

2013

\section{Systematic analysis of carbon nanotubes toxicity in cellular systems}

Gabrielle Rogers-Nieman
West Virginia University

Follow this and additional works at: https://researchrepository.wvu.edu/etd

\section{Recommended Citation}

Rogers-Nieman, Gabrielle, "Systematic analysis of carbon nanotubes toxicity in cellular systems" (2013). Graduate Theses, Dissertations, and Problem Reports. 4996.

https://researchrepository.wvu.edu/etd/4996

This Thesis is protected by copyright and/or related rights. It has been brought to you by the The Research Repository @ WVU with permission from the rights-holder(s). You are free to use this Thesis in any way that is permitted by the copyright and related rights legislation that applies to your use. For other uses you must obtain permission from the rights-holder(s) directly, unless additional rights are indicated by a Creative Commons license in the record and/ or on the work itself. This Thesis has been accepted for inclusion in WVU Graduate Theses, Dissertations, and Problem Reports collection by an authorized administrator of The Research Repository @ WVU. For more information, please contact researchrepository@mail.wvu.edu. 


\title{
Systematic analysis of carbon nanotubes toxicity in cellular systems
}

\author{
By \\ Gabrielle Rogers-Nieman \\ Thesis submitted to the Benjamin M. Statler College of Engineering and Mineral Resources at \\ West Virginia University \\ in partial fulfillment of the requirements for the degree of \\ Masters of Science \\ in
}

Chemical Engineering

Committee Members

Cerasela Zoica Dinu, Committee Chairperson

Linda Sargent

Yong Yang

Morgantown, West Virginia

2013

Keywords: mitotic spindle, Eg5, dynein, genotoxicity, functionalized, MWCNT, cell cycle, in vitro 


\section{$\underline{\text { Abstract }}$}

As the applied use for carbon nanotubes (CNTs) increases across engineering and biomedical sectors, a clear understanding of the deleterious effects surrounding CNT-induced toxicity, namely genotoxicity, is required. Currently, the exact genotoxic mechanisms that surround CNT-induced mitotic disruption that result in aneuploidy are not completely understood. Thus, there is a need for clear mechanical models to be formulated. Herein a comprehensive overview of the nanotube toxicity is provided insisting on the aspects related to CNTs genotoxicity.

In Chapter 1, I am providing a review of the current research in the CNT-s induced toxicity. I start by defining these members of the fullerenes family and subsequently talk about their implementation in a variety of applications from interconnects to composite polymers, from electrodes to high temperature fillers, from bioimaging to biosensors, and finally in drug delivery. Next, I introduce aspects related to the CNT toxicity in vitro and in vivo, both in relation to the cytotoxicity and genotoxicity specifically focusing on what is currently known about CNT-induced genotoxicity and suggesting more research in the area of critical mitotic mediators i.e. the cytoskeletal filament, microtubules and their associate mitotic molecular motors, while also proposing an application for CNT use in targeted drug delivery, respective of molecular motor targets. Lastly, my Chapter focuses on the current research in CNTs-induced genotoxicity and proposes a more exact model of the aneuploidy that could take place upon cellular exposure. Such findings could lead to designing novel CNT-based platforms to improve chemotherapeutic efficiencies for targeted delivery and cancer therapeutics. However, this Chapter also points out that the goal for CNT use in cancer therapy will require convergence to minimize host cytotoxicity, while maximizing cancer cell genotoxicity.

In Chapter 2, I describe functionalized MWCNT-induced mitotic disturbances following in vitro exposure of BEAS-2B, human bronchial epithelial cells. I present distinctly different characterizations between the degree of MWCNT functionalization and how that affects the cellular response. Following cell treatment changes in the cell cycle have been observed, resulting in cell cycle arrest, that correlate with changes in mRNA expression of molecular 
motors, dynein and $\mathrm{Eg} 5$, resulting in a reduction of total protein expression in a time dependent manner. This study is the first to show MWCNT-induced disruptions of critical mitotic mediators, i.e. molecular motor proteins dynein and Eg5, and one of several studies that confirm clear disruptions in the cell cycle following exposure to functionalized MWCNTs, thereby providing a viable mechanical model for the CNT-induced genotoxicity. 


\title{
$\underline{\text { Dedication }}$
}

\author{
In loving memory \\ Douglas Bruce Rogers \\ (December 13, 1984 - January 30, 2011) \\ "Forever in our Hearts"
}

To my children, Lorelei and Jack

"There are great survivors and helpless victims on the curve of human ability. Most of us are neither. Most of us fall somewhere in between and may perform poorly at first, then find the inner resources to return to correct action and clear thought. If the object of the game is survival, that will do."

\section{Laurence Gonzales "Deep Survival”}

I will stop at nothing to ensure there is hopefulness and happiness in the very bright futures that await you; I encourage you to do the same.

I love you more than infinite space, you have given meaning to my life.

Love Always and Forever

Your Mommy, Gabrielle 


\section{$\underline{\text { Acknowledgements }}$}

My pursuance of a second master's degree in Chemical Engineering was made possible through the generosity and guidance of my research advisor, Dr. Cerasela Zoica Dinu. With Dr. Dinu, our every interaction was an exercise in forming my aptitude as a scientific professional and upstanding community member. I deeply thank Dr. Dinu for her expertise, her time, her enthusiasm and her patience. Additionally, I have had the rare opportunity to work at the Centers for Disease Control - National Institute for Occupational Safety and Health facility in Morgantown, WV; I sincerely have to thank Dr. Linda Sargent and Dr. Steve Reynolds, who agreed to allow me to work within their lab, and shared their insight. Further, I would like to thank all my committee members, Dr. Cerasela Dinu, Dr. Linda Sargent and Dr. Yong Yang, for your time and dedication.

I also want to acknowledge the helpful insight of my peers, and thank, Reem Eldawud, Chenbo Dong and Alan Campbell; the future's bright scientific minds. Additionally, I want thank the Department of Chemical Engineering faculty and staff for giving me an opportunity to improve my quality of life with further education. I have never worked so hard or been so mentally challenged in my life; it is a completely gratifying experience to know that I have accomplished this task and that I had fun in the process. I have nothing but the highest respect for this department; it does what it does very well.

Lastly, I have to acknowledge and thank my support system; my husband Eric, my mom Theresa, my dad Robert, my brother Douglas, my sister Paola, and my children Lorelei and Jack, as well as all other family and friends who supported me throughout this process; all this would not have been possible if not for your love. This program taught me a lot about inner challenge, but my family taught me more about inner belief. The latter was my hardest lesson, but ultimately the most important one.

God has blessed me beyond belief, and I am eternally grateful.

My most sincere "Thank You" to you all. 


\section{Table of Contents}

Abstract..............................................................................iii

Dedication..................................................................................iv

Acknowledgements.........................................................................v

Table of Contents.................................................................... vi

List of Figures..................................................................... vii

List of Tables............................................................................... viii

Chapter 1: The Exploitation of Subtle Genotoxic Associations between Carbon Nanotube, Microtubules, and Molecular Motors for Possible use in Cancer Therapeutics.................1

Chapter 2: Changes in the Dynein and Eg5 Expression Profiles following Exposure of Epithelial Cells to Multiwalled Carbon Nanotube.....................................22 


\section{$\underline{\text { List of Figures }}$}

Chapter 1: The Exploitation of Subtle Genotoxic Associations between Carbon Nanotube, Microtubules, and Molecular Motors for Possible use in Cancer Therapeutics

Figure 1: A schematic diagram showing the emerging engineering applications of carbon nanotubes (CNTs). 3

Figure 2: A summary of the toxicological mechanisms induced by single-walled and multi-walled carbon nanotubes in vivo and in vitro exposure....................6

Figure 3: Copyrighted from A) Sargent et al., doi:10.1016/j.mrgentox.2011.11.017, and B) Rodriguez-Fernandez et al., doi: 10.1021/nn302222m.

Figure 4: A) A diagram of the eukaryotic cell mitotic spindle B) A diagram of the eukaryotic cell mitotic spindle following CNT exposure.

\section{Chapter 2: Changes in the Dynein and Eg5 Expression Profiles following Exposure of Epithelial Cells to Multiwalled Carbon Nanotube}

Figure 1A: Histogram of Average Length Distribution......................30

Figure 1B: Graph of Raman Spectra Results............................32

Figure 1C: Graph of MWCNT Solubility................................34

Figure 2: Cell Treatment and Analysis Summary Diagram: Procedural Overview of Experiments...................................................... 35

Figure 3: Graph of Flow Cytometry Cell Cycle Analysis.......................38

Figure 4A: Graph of Dynein mRNA Expression.........................40

Figure 4B: Graph of Eg5 mRNA Expression..........................41

Figure 5 (A and B): Comparative Overview of Mitotic Spindle Formation-following treatment with MWCNTs................................................. 


\section{$\underline{\text { List of Tables }}$}

Chapter 1: The Exploitation of Subtle Genotoxic Associations between Carbon Nanotube, Microtubules, and Molecular Motors for Possible use in Cancer Therapeutics

Table 1: A summary of the toxicological mechanisms induced by single-walled and multi-walled carbon nanotubes in vivo and in vitro exposure....................6

Chapter 2: Changes in the Dynein and Eg5 Expression Profiles following Exposure of Epithelial Cells to Multiwalled Carbon Nanotube

Table 1: Summary Table of Raman Histogram Results........................31

Table 2: Summary Table for EDX Analysis..............................31

Table 3: Summary Table of Flow Cytometry Cell Cycle Analysis for G1 and S phases 


\title{
Chapter 1
}

\section{The exploitation of subtle genotoxic associations between carbon nanotube, microtubules, and molecular motors for possible use in cancer therapeutics}

\begin{abstract}
$\underline{\text { Abstract }}$
Carbon nanotubes (CNTs) have been proposed as the next generation vehicles to be used in cancer therapy. Based on their thermal, optical, electrical and mechanical properties that allows for targeted delivery ', their large surface area that allows for efficient drug loading ${ }^{2,3}$, as well as their ability to localize and be visualized at the tumor site ${ }^{4,5}$, CNTs can induce effective killing of tumor cells ${ }^{6}$ by cell lysis ${ }^{l}$. Even though the potential for novel CNTchemotherapeutic platforms may exist ${ }^{7}$, research needs to proceed with caution and account for their cytotoxic and genotoxic mechanisms. Herein we review the recent advances in understanding the toxicological aspects related to carbon nanotube cellular exposure and highlight the roles of structural cellular elements in cellular genotoxicity. Further, we suggest novel means to investigate and exploit the potential of carbon nanotubes to serve as the next generation of tailored chemotherapeutics that actively inhibit cancer cell development.
\end{abstract}

\section{$\underline{\text { Introduction }}$}

Current cancer therapeutics lack the specificity to target only cancer cells and instead cause toxicity throughout the whole body ${ }^{8,9}$ thus patients succumb to death ${ }^{10}$. The early detection of host toxicity presents a multifaceted challenge for healthcare professionals on a runaway time axis ${ }^{11}$. Further, current in-use chemotherapeutics are being challenged by drugresistance ${ }^{12}$, as is the case with taxol, a chemotherapeutic that targets the cytoskeletal filament microtubule (MT) ${ }^{13}$ with roles in cellular division. Additionally, short resonance times ${ }^{14}$ and low dispersity ${ }^{15,16}$ play a role in the greater inefficiencies of traditional chemotherapeutics. A more effective strategy capable of targeting tumor cells without affecting healthy cells is needed in order to tailor individual treatments. 
CNTs are members of the fullerene families and allotropes of carbon ${ }^{17-19}$. CNTs are known for their high aspect ratios, with typical diameters ranging from 1-100 nm and lengths up to several centimeters ${ }^{18}$. CNTs are categorized as single-walled or multi-walled carbon nanotubes (SW- or MWCNTs), where SWCNTs refer to a single rolled graphene sheet with diameters ranging from 0.4 to $3 \mathrm{~nm}$, while MWCNTs refer to multiple rolled graphene sheets stacked inside one another and have diameters ranging from 2 to $100 \mathrm{~nm}^{17-23}$. CNTs are stiff and resilient structures with an average Young's modulus of $>1 \mathrm{TPa}{ }^{24}$. This resilience allows the nanotubes to be exposed to extreme "bending" torsion or "sliding" shear forces and return to their original shape without reaching material failure ${ }^{22,25-29}$. The unique combination of CNTs properties and their intrinsic mechanical ${ }^{22}$ and electrical properties ${ }^{20,21,23}$, make the nanotubes ideal candidates for a wide variety of applications from interconnects in micro-electronic devices ${ }^{30,31}$, to oxide semi-conductor field effect transistors (MOS-FET) ${ }^{32-34}$, from electrodes for lithium-ion batteries ${ }^{35-38}$, to load-bearing reinforcements in composites ${ }^{39-43}$, and from high temperature fillers ${ }^{44-46}$, to microcatheter polymer composites able to reduce thrombogenesis and blood coagulation ${ }^{47}$. CNTs recent functionalization with biological molecules such as DNA ${ }^{48,49}$, RNA ${ }^{48}$, enzymes ${ }^{50,51}$ and proteins ${ }^{52}$ have led to nanotubes being explored as novel, and innovative tools with applications in bioimaging ${ }^{53,54}$, on biosensor platforms ${ }^{55}$, and for targeted delivery of drugs ${ }^{56,57}$. A summary of the applications of CNTs in synthetic environment is shown in Figure 1. 


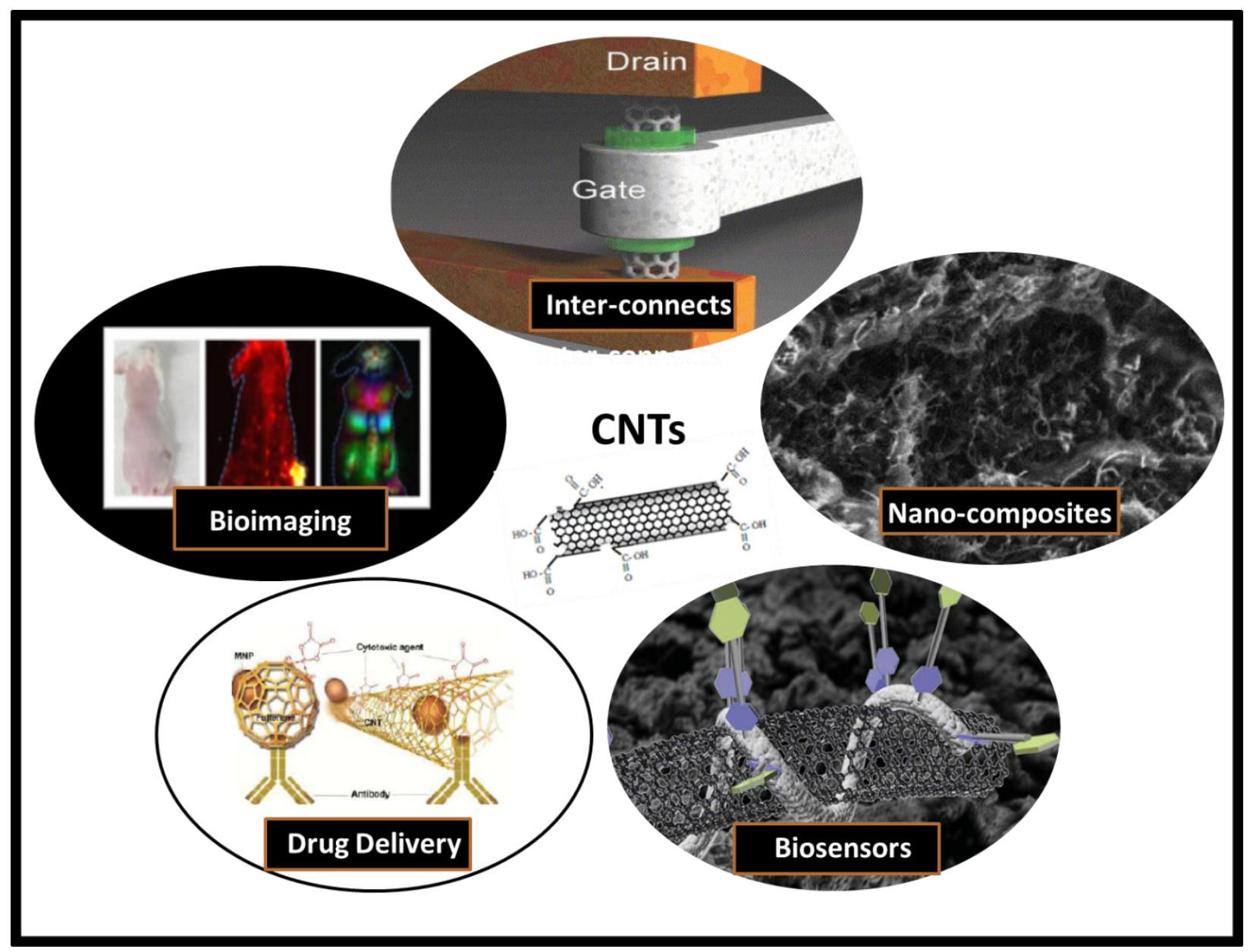

Figure 1: The schematic diagram shows the emerging engineering applications of carbon nanotubes (CNTs): Bioimaging, figure adapted from Robinson et al., ${ }^{54}$ doi: 10.1021/ja303737a, Drug Delivery, figure adapted from Omidi et al., ${ }^{58}$ doi: 10.5681/bi.2011.028, Biosensors, figure adapted from Shi et al., ${ }^{59}$ doi: 10.1039/C1AN15179G, Microelectronic Inter-connects, figure adapted from Graham et al., ${ }^{31}$ doi: 10.1016/j.diamond.2003.10.080, and Nanocomposites, figure adapted from Fan et al., ${ }^{43}$ doi: 10.1016/j.mseb.206.02.045.

As carbon nanotubes (CNTs) make a fast break into the vast world of nanotechnology, so follows our interest to harness their exceptional properties. The question remains, can we use CNTs for cancer therapy? In this article, we first review the current status of available methodologies for applications of CNTs in the biomedical engineering and biotechnology; subsequently we discuss the toxicological aspects related to CNT exposure in biological systems and define implications of CNT-induced genotoxicity, and lastly propose viable means to exploit CNTs properties for designing CNT-based platforms for tailored cancer therapeutics. 


\section{Carbon nanotubes in bio-related disciplines}

In bioimaging, Khandare et al, have shown that MWCNTs conjugated via polyethylene glycol (PEG) spacer to fluorescein isothiocyanate (FITC) have a faster cellular uptake and reach the perinuclear area of the breast cancer cell line, MCF7, cells faster than FITC alone ${ }^{60}$. Cherukuri et al., have explored SWCNT intrinsic fluorescence to demonstrate uptake in macrophages ${ }^{61}$. For biosensors applications, Pan et al., have shown that immobilization of CNTs with glucose oxidase (GOD), and poly(o-aminphenol) (POAP) on gold(Au) electrodes, increased sensitivity of an amperometric glucose biosensor, resulting in lower detection limits, and thus larger responses when compared to GOD/POAP/Au electrodes alone ${ }^{62}$. Further, Kurkina et al., reported on the use of CNTs in an electrochemical biosensing platform for the detection of low target DNA sequence concentrations for point of care applications. In this particular study, SWCNT-based biosensors showed, on order of magnitude lower detection capability when compared to currently used silicon nanowires ${ }^{63,64}$ for target synthetic DNA sequences that comprised only $2 \%$ of the total DNA pool ${ }^{65}$. Lastly for drug delivery, Wu et al., showed MWCNTs functionalization with amphotericin B (AmB), an antibiotic that treats fungal infections and is otherwise toxic to mammalian cells if used free in solution. In their study, the CNT-AmB conjugates showed effective killing capability of $C$. parapsilosis, $C$. albicans, and $C$. neoformans fungi colonies, with no simultaneous toxicity towards Jurkat T-lymphocytes cells ${ }^{3}$. Complementary, Liu et al., showed that SWCNT-taxol conjugates, significantly decreased tumor weight and increased apoptosis in mouse T41 breast cancer in vivo models when used for cancer therapy. The authors also observed a 10-fold higher uptake of these conjugates in the tumor cells 2 . However, despite these examples that show CNTs implementation in biomedical engineering ${ }^{66,67}$ and biotechnology ${ }^{53,55-57}$, there are several factors that hinder CNTs full potential for use as therapeutic vector agents for drug and gene transfection into cellular systems ${ }^{68}$. Further, while carbon nanotubes have been vied as the "wonder solution" for cancer therapeutics ", a clear understanding of how they effectively kill, mechanistically, still remains ill defined ${ }^{68}$. These limitations are associated with the lack of consistency in toxicological and pharmacological studies that assess CNTs relatable exposure hazards and how such exposures do or do not lead to cellular harm ${ }^{69}$. 


\section{Cytotoxicity associated with CNT exposure}

Exposure hazard and toxicity related to CNTs are likely to occur in production and manufacturing settings where nanomaterials can aerosolize and aggregate into a concentrated area ${ }^{70-73}$, and thus be easily inhaled ${ }^{74-78}$. Current exposure limits for CNTs fall under the category of "particles not otherwise regulated" at a $5 \mathrm{mg} / \mathrm{m}^{3}$ exposure concentration ${ }^{79}$. The primary models used for detecting work-relatable exposures are from inhalation studies using rats and mice. The recommended exposure limit (REL) of $7 \mu \mathrm{g} / \mathrm{m}^{3}$, was calculated assuming $8 \mathrm{~h}$ work shifts, $40 \mathrm{~h}$ per week work schedules for 50 weeks per year for a duration of 45 years ${ }^{80}$. Further in vivo rat and mouse acute and sub-chronic studies ${ }^{74-78,81-84}$ provided evidence for the determination of the benchmark dosage (BMD) for human exposures by accounting for differences in alveolar lung surface area ${ }^{80}$. Research has shown that following inhalation of particles of low solubility two distinct pathways are responsible for induced toxic changes. The primary path depends highly on the intrinsic activity of the particles themselves, while the secondary path is relative to the inflammatory events that are elicited following exposure to the tissue $^{85}$.

Across in vivo and in vitro studies, CNT type, functionalization, dispersion, ${ }^{56,86}$ and dosage all seem to relate to toxicity, and in cases, have led to conflicting reports. A summary of cyto- and genotoxicity of both SW- and MWCNTs is shown in Figure 2. For instance, some studies have suggested that functionalized CNTs i.e. low metal, high carbon compositions versus non-functionalized or pristine CNTs i.e. high in metal impurities at low dosages, are free of cytotoxic insult to cells ${ }^{87-90}$. Other studies have however shown that following exposure to either SW- or MWCNTs, pulmonary toxicity ${ }^{74-78}$ and the potential for carcinogenesis is induced 91,92. In vivo studies have shown that CNT exposure leads to granuloma formation ${ }^{76-78}$, pulmonary fibrosis ${ }^{76-78}$ involving bronchiolar and alveolar epithelial cells, formation of reactive oxygen species (ROS) ${ }^{83,93}$, up-regulation of the innate immune system and observation of macrophages with multiple or no nuclei ${ }^{81}$. In vitro studies have shown disruption of the mitotic spindle ${ }^{94}$, ROS generation, ${ }^{90,95,96}$ up-regulation of pro-inflammatory pathways ${ }^{95,97-99}$ as well as micronuclei formation ${ }^{93,100,101}$ and fragmentation of DNA ${ }^{96,101-103}$. Ding et al., have shown that exposure to high concentrations of MWCNTs led to quick innate immune responses through type I interferon (IFN) signaling. Such a response up-regulated several pro-inflammatory cytokines, 
including but not limited to, tumor necrosis factor-alpha (TNF- $\alpha$ ), BCL-like-protein 2 (BCL2L2) and induced myeloid leukemia cell differentiation protein-1 (MCL1), a key regulatory protein of apoptosis ${ }^{97}$. Additionally, generation of ROS following treatment with SWCNTs was shown to lead to impaired DNA repair function and subsequently to apoptosis through poly-ADP-ribose polymerase (PARP) cleavage ${ }^{96,97}$. Further, it appears that SWCNT treatment stimulates activation of important transcription factors i.e. activator protein-1(AP-1) and nuclear factorkappa light chain enhancer of activated B cells $(\mathrm{NF}-\kappa \mathrm{B})$ which are mediated by upstream kinase regulation through stimulation of extracellular signal regulated kinases (ERKs), Jun-N-terminal kinases (JNKs) and protein p38 ${ }^{96}$. These analyses suggested that the induction of p38/ERK pathway and the type 1 IFN signaling response are responsible for down-stream transcriptional changes following exposure ${ }^{96,97}$.

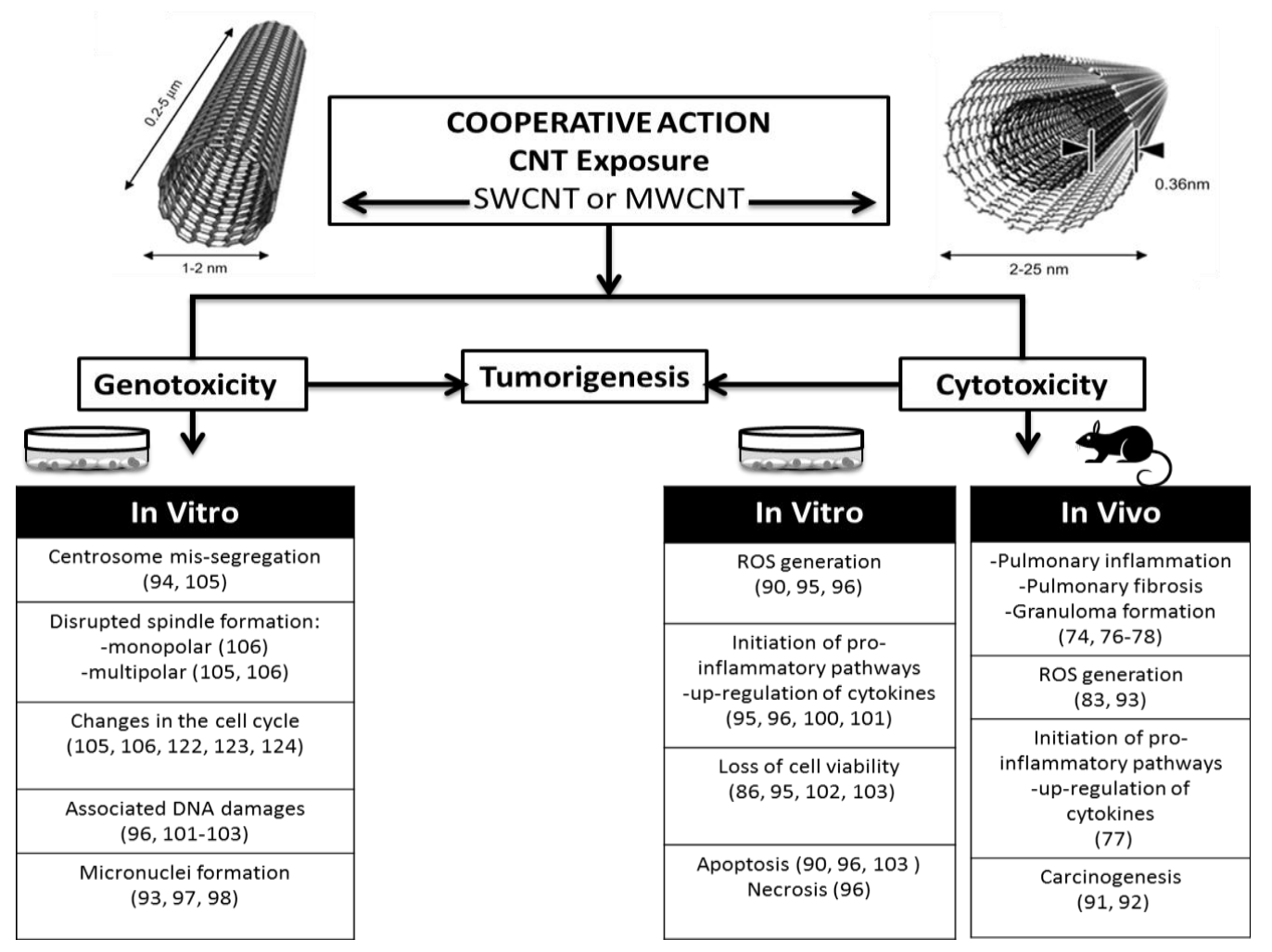

Figure 2: In vivo and In vitro exposure to carbon nanotubes (CNTs) lead to cyto- and genotoxicity, a summary of the toxicological mechanisms induced by single-walled and multiwalled carbon nanotubes (SW- and MWCNTs). CNT (SW- and MWCNTs) figures adapted from Raymond Reilly ${ }^{104}$ doi: 10.2967/jnumed.107.04.1723. 


\section{A closer look at the mechanisms of CNTs-induced cellular genotoxicity}

Studies following treatment with either SW- or MWCNTs have also reported observable changes in normal cell cycle progression. For instance, following exposure to either SW- ${ }^{105}$ or MWCNTs ${ }^{106}$, cells were observed leaving G1 phase, likely following mitotic "slippage", only to subsequently sequester in $\mathrm{S} / \mathrm{G} 2$ phases in response to treatment ${ }^{107}$. Mitotic slippage occurs when cells escape mitotic arrest and subsequently divide, without even distribution of genetic copies to progeny cells. Further, the cells enter the G1 phase and no further cellular division occurs ${ }^{107}$. Studies involving SWCNTs showed nanotube integration with the cellular elements and disruption of the cellular centrosome ${ }^{105}$ (Figure 3A), with similar effects of aberrant mitotic spindles observed for MWCNTs (Figure 3B) ${ }^{106}$. Other reports indicate global DNA damage ${ }^{108}$, or inhibition of the mitotic spindle assembly and movement ${ }^{109,110}$.

A)
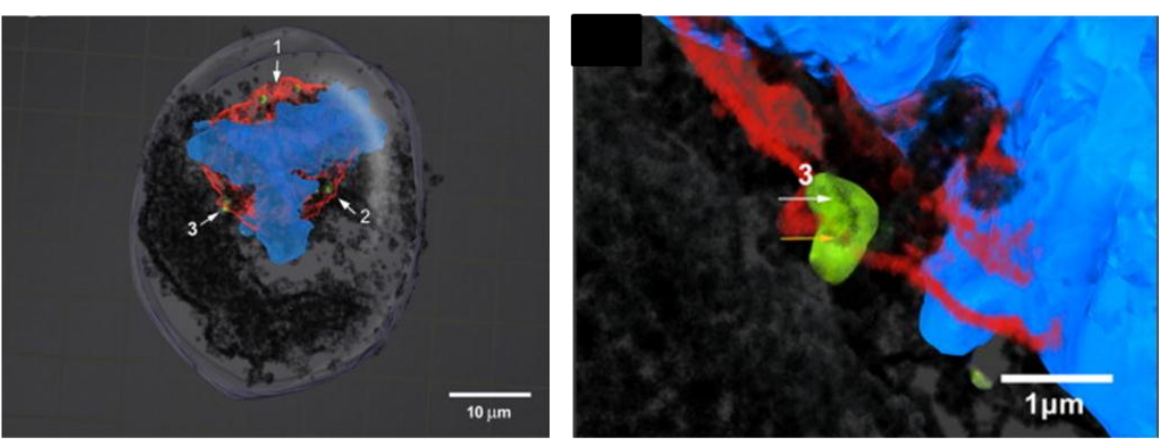

B)
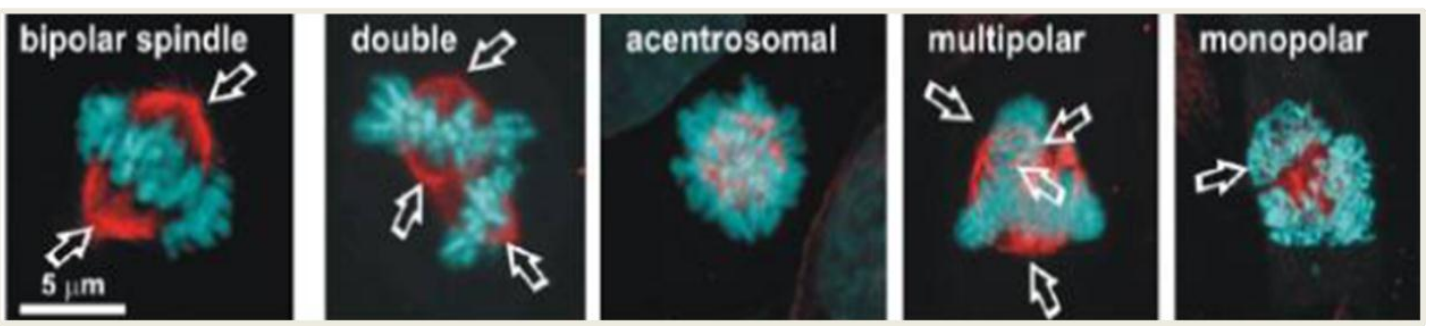

Figure 3: A) A 3D reconstruction of the multipolar mitotic spindle with three poles. The DNA is blue, the tubulin is red, the centrosomes are green and the nanotubes are black. The three spindle poles are indicated by white arrows. Serial optical sections of $0.1 \mu \mathrm{m}$ in depth were used to construct a 3D image of the tripolar mitosis. The reconstructed image shows nanotubes inside the cell in association with each centrosome fragment at the 3 spindle poles. Nanotubes are also 
integrated with the microtubules and the DNA. In the centrosomes and the portion of the mitotic spindle labeled as region 3 in are increased in size to show details of the nanotube association with the centrosome and the tubulin. The nanotubes can be seen within the centrosome structure as indicated by the white arrow. The nanotubes associated with the microtubule can also be seen in more detail as indicated by the yellow arrow. In this cell, the three spindle poles, the three unequal DNA bundles, and the disruption of microtubule attachments to two centrosomes suggest major perturbations in cell division, , figure copyrighted from Sargent et al., ${ }^{105}$ doi: 10.1016/j.mrgentox.2011.11.017 . B) Confocal microscopy projection images of aberrant mitotic spindles in cells treated with MWCNTs. Aberrations in the organization of the spindle microtubules (red channel) and chromosomal distribution (blue channel) are observed, figure copyrighted from Rodriguez-Fernandez et al., ${ }^{106}$ doi: 10.1021/nn302222m.

Mitotic spindles formation ${ }^{111}$ is driven by the integration of the structural framework of microtubule (MT) cytoskeletal filaments ${ }^{112,113}$. MTs are formed by polymerization of $\alpha$ and $\beta$ subunits of tubulin ${ }^{114}$. The $\alpha$ and $\beta$ tubulin dimers orient in a head to tail fashion and lead to protofilaments formation; 13 protofilaments associate laterally to form the MT structure ${ }^{115}$. Both subunits bind guanidine triphosphate (GTP), however only the GTP bound to the $\beta$-subunit is hydrolyzed during polymerization. This allows for fast addition of other $\beta$-subunits and thus a "fast growing" or "plus end" of the microtubule. The GTP bound to the $\alpha$-exposed end is not hydrolyzed, thus making the $\alpha$-exposed end the "slow growing" or "minus end" of the MT structure ${ }^{115}$. MTs have an average diameter of $25 \mathrm{~nm}$, and make up the "tracks" used by the molecular motors for organelles movement throughout the cell during interphase ${ }^{116}$. Specifically, the MTs begin to nucleate, grow, and organize prior to centrosome duplication and separation ${ }^{111,117,118}$. MT nucleation starts at the microtubule organization center (MTOC) with $\gamma$ tubulin ring formation encapsulating the minus end of the MTs, followed by the $\alpha$ and $\beta$-subunit polymerization ${ }^{111}$, and finally orientation of the MT plus ends towards the cell periphery. ${ }^{111,119}$ Later, beginning in prophase, MTs make up the framework for the mitotic spindle formation ${ }^{116}$.

MWCNT exposure to cells in vitro have been described as both clastogenic, leading to disruption or breakage of chromosomes observed by formation of micronuclei, and aneugenic, whereby exposure affects cellular division and mitotic spindle formation ${ }^{93}$. Muller et al. 2008, reported that MWCNT exposure causes both clastogenic and aneugenic effects that lead to whole 
or partial loss of chromosomes ${ }^{93}$ similar to known carcinogen crocidolite asbestos ${ }^{96,120,121}$. Further, the display of a mitotic checkpoint response following treatment with either $\mathrm{SW}^{122}$-or MWCNTs ${ }^{123}$ and blockage in normal progression toward cell proliferation suggests that CNTs treatment may also result in impaired phosphorylation cascades, and/ or deviations in transcriptional regulation of important cell cycle regulators. As seen by Zhang et al., treatment with carboxylated MWCNTs mediates over-expression of cyclin-dependant kinase inhibitor 1 (p21), a known inhibitor of CDK1 \& 2, and is independent of tumor protein 53 (p53) protein expression via impaired bone morphogenic protein (BMP) signaling, suggesting that p21 itself mediates cell cycle arrest in response to treatment ${ }^{123,124}$. Further, Nam et al., have shown a significant reduction in CDK2 and CDK6 cell cycle proteins in normal rat kidney epithelial cells treated with sodium dodesoyl sulfate (SDS) functionalized SWCNTs. In this study, reduced phosphorylated-retinoblastoma (pRB) and lowered cell viability, as well as increased p53 and p21 expression and growth arrest at the G0/G1 phase border was observed ${ }^{122}$. However, the exact mechanisms that lead to defects in the mitotic spindle and results in aneuploidy following CNT exposure have yet to be fully explained.

\section{The role of microtubules and molecular motors in CNTs-induced genotoxicity}

CNTs have been observed in proximity to cellular and mitotic tubulin, in the mid-body region separating two daughter cells, and in association with MTs ${ }^{94,105,106}$. Further, in vitro polymerization of tubulin onto CNTs scaffolds led to biohybrid formation ${ }^{52}$. Such biohybrids consisting of bundles of CNTs encapsulated by augmented MTs with impaired microtubule function ${ }^{125}$. Taking into account the association of the tubulin with CNTs, as well as previous observations of the inhibition in mitotic spindle assembly movement ${ }^{109,110}$ and abnormal spindle formation as result of CNT treatment ${ }^{105}$, a closer look on the role that CNTs play in mitotic spindle assembly and disassembly is required. In particular, studies are required to evaluate how nanomaterial-MT-molecular motor associations can affect mitotic assembly and cell division $94,105,106,126$.

In eukaryotic cells, dynein, Eg5, Kin14 and Kin4/Kin10 are mitotic molecular motors required to achieve meaningful cellular division ${ }^{127}$. These molecular motors move along the MT in a directional way following ATP hydrolysis at their respective motor domains and participate in the cellular division process ${ }^{128,129}$ generating directional force to segregate two daughter cells 
129,130. A representation of the cellular mitotic spindle and the molecular motors involved in spindle formation is shown in Figure 4A. For instance, during prophase dynein walks towards the minus end of the MTs and in association with dynactin ${ }^{119,131-135}$ is responsible for providing the pulling force necessary to segregate replicated centrosomes to either polar end of the cell 136,137. Further, through force oscillations ${ }^{126}$ with Eg5 the two motors provide mitotic spindle stability throughout mitosis ${ }^{117,118,138-140}$. Eg5 is a member of the Bim-C family, a homotetrameric plus end directed molecular motor known to be essential for normal division of cells ${ }^{141-145}$. Under ATP hydrolysis Eg5 slides the anti-parallel, inter-polar MTs; this movement is responsible for providing a pushing force to keep the two centrosomes at their respective polar ends ${ }^{141,143-147}$. Additional roles of Eg5 have been studied in relation to astral MTs where Eg5 movement towards minus end was observed in early mitosis, which coincidently, required binding to dynein to aid in centrosome segregation following nuclear envelop breakdown ${ }^{131}$. Kinesin-14 is known as C-terminal or Ned kinesin, also binding inter-polar MTs, like Eg5, with Kin-14's movement proceeding toward the minus end of the MT ${ }^{148,149}$. The ability to slide the force generating inter-polar MTs toward the minus end with Kin-14 and the plus end with Kin-5 ensures proper mitotic spindle balance for equal chromosome segregation during cell division 111. Kinesin 4 and 10 are known as chromo-kinesins and are found in all eukaryotic cells. These kinesins associate with the arm of the chromosome and their movement under ATP hydrolysis is directed toward the plus end of the kinetochore MTs, which helping with chromosomal positioning along the metaphase plate ${ }^{149}$.

Inhibition of such molecular motors has shown to have similar effects to exposure to CNTs. In particular, following Eg5 inhibition, monopolar spindle formation ${ }^{150}$ has been observed. Further, studies have shown that when Eg5 is inhibited either by Eg5 siRNA downregulation ${ }^{151,152}$, or by administration of small molecule inhibitors ${ }^{91,107}$, disruptions in mitotic spindle formation occur. Inhibition also results in an "arrest-like" status via abrogation of checkpoints leading to mitotic catastrophe, similarly to cellular exposure to nanomaterials. Thus, CNTs interaction with MTs and molecular motors involved in cellular division may lead to mechanical force imbalances within the spindle assembly and alteration of key regulatory pathways that affect protein transcription and expression ${ }^{97-99}$, which ultimately lead to aneuploidy ${ }^{93,94}$ a precursor to early tumorigenesis. 
Based on these findings, we can begin to piece together a more exact model for CNTinduced genotoxicity (Figure 4B). A timeline will be required to show how early CNT-induced phosphorylation impairment leads to down regulation of mitotic motor expressions, which then disrupts the formation of the mitotic spindle, while at the same time pushing the cell toward cell cycle arrest. In addition, an in vivo model will be required to provide evidence about how CNT treatment can affect the normal association and movement of mitotic motors along MTs. Thus, in addition to the traditional approaches of investigating genotoxicity and the events that lead to CNT-induced aneuploidy ${ }^{153}$, research should also focus on observing and quantifying CNT-MT and CNT-molecular motor protein associations in real time. For a better description of disruptions in mitotic spindle formation, possibly through altered force oscillations via loadaccelerated protein-protein dissociation ${ }^{129,154}$ we must first observe real time changes, respective of both MTs and molecular motor proteins, as a result of exposure with CNTs.

A)

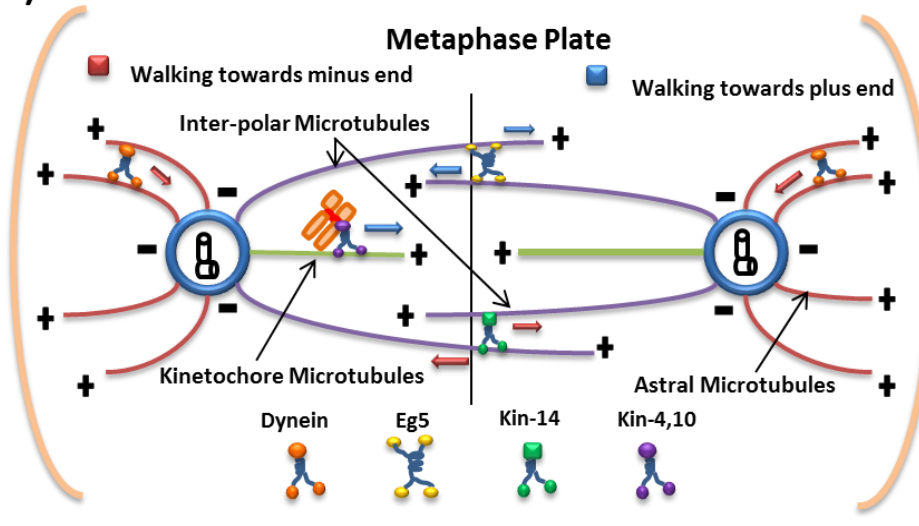

B)

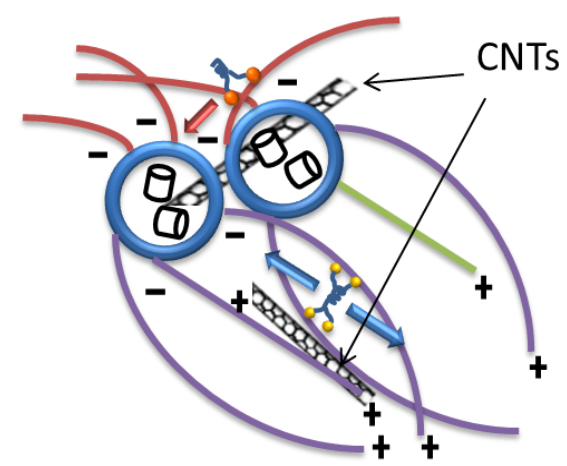

Figure 4: A) A diagram of the eukaryotic cell mitotic spindle: There are three distinct types of microtubules (MTs): Kinetochore MTs bind to the minus end of the centrosome and then attach to the kinetochore of the sister chromatids at the MT plus end, Inter-polar MTs bind to the minus end to the centrosome, and then overlap in the mid-zone region of the mitotic spindle. Interpolar MTs do not have a chromosomal attachment point. Astral MTs bind to the minus end of the centrosome, and then plus ends grow outward toward the cell cortex. Additionally, the eukaryotic mitotic molecular motors, Dynein, Eg5, Kinesin-14, and Kinesin-4 and 10 move in association with MTs via ATP hydrolysis, and provide directional movement required for proper 
spindle formation. Under normal cell cycle conditions MTs and mitotic molecular motors work in concert to achieve bipolar spindle assembly. B) Following CNT exposure, CNTs can interact with the centrosomes, the microtubules and mitotic molecular motors to inhibit proper spindle formation. Lack of association of the mitotic molecular motors with the CNTs-microtubule biohybrids could lead to mis-positioning of the centrosomes and genotoxicity.

\section{Making the best of the worst: CNT use in cancer therapy}

Can we use CNTs for the better? Can we envision using their interactions with the molecular motors and microtubules when designing novel CNT-based platforms to improve chemotherapeutic efficiencies by way of higher dispersities, and more targeted delivery? ${ }^{7}$ Deciding on whether the reality for CNT use in cancer therapy is hopeless or not, is a matter of perspective. If we consider association of CNTs with MTs and molecular motors, both in vitro and in vivo that leads to cyto- and genotoxicity, we may say "no". However, if we consider association of CNTs with MTs and molecular motors that escape cytotoxic pathways while at the same time effectively targeting genotoxic pathways, in addition to exploiting CNTs properties for improved dispersity, drug-loading, and targeted delivery potential, then we may say "yes". Thus, while ensuring that we minimize the costs/risks involving CNT implementation into chemotherapeutics we can at the same time suggest a compromise to achieve greater benefits i.e. better therapeutic outcomes. By designing a more "global" approach in which the user will be 1) inhibiting cancer cell cycle regulatory cascades, 2) inducing down regulation of mitotic motor protein expression, and 3) impairing the ATP hydrolyzed directional movement of motors along MTs, one can program cancer cell death or rather cell cycle arrest for cancer cells only. The key here is to find an effective dosage concentration range relative to the type of CNT, an optimal functionalization for the CNT surface, and achieve full dispersion of CNTs in the dosing media. The goal for CNT use in cancer therapy will require convergence to minimize host cytotoxicity, while maximizing cancer cell genotoxicity. 


\section{References}

1 Zhang W, Z. Z., Zhang Y. The application of carbon nanotubes in target drug delivery systems for cancer therapies. Nanoscale Research Letters 6, 1-22 (2011).

2 Liu Z, C. K., Davis C, Sherlock S, Cao Q, Chen X, Dai H. Drug Delivery with Carbon Nanotubes for In vivo Cancer Treatment. Cancer Res 68, 6652 (2008).

3 Wu W, W. S., Pastorin G, Benincasa M, Klumpp C, Briand JP, Gennaro R, Prato M, Bianco A. Targeted delivery of amphotericin B to cells by using functionalized carbon nanotubes. Angew Chem Int Ed Engl 44, 6358-6362 (2005).

$4 \quad$ Al Faraj A, C. K., Lacroix G, Gaillard S, Canet-Soulas E, Cremillieux Y. In vivo imaging of carbon nanotube biodistribution using magnetic resonance imaging. Nano Lett 9, 1023-1027 (2009).

5 Al Faraj A, F. F., Luciani N, Lacroix G, Levy M, Cremillieux Y, Canet-Soulas E. In vivo biodistribution and biological impact of injected carbon nanotubes using magnetic resonance techniques. Int J Nanomedicine 6, 351-361 (2011).

6 Yu JG, J. F., Chen XQ, Jiang XY, Peng ZG, Zeng DM, Huang DS. Irradiation-mediated carbon nanotubes' use in cancer therapy. Journal of Cancer Research and Therapeutics 8 , 348-354 (2012).

7 Madani SY, N. N., Dissanayake O, Tan A, Seifalian AM. A new era of cancer treatment: carbon nanotubes as drug delivery tools. Int J Nanomedicine 6, 2963-2979 (2011).

8 Gharib MI, B. A. Chemotherapy-induced cardiotoxicity: current practice and prospects of prophylaxis. European Journal of Heart Failure 4, 235-242 (2002).

9 Perry, M. The Chemotherapy Source Book. (Lippincot Williams \& Wilkins2008).

10 O'Brien MER, B. A., Rigg a, Leary A, Assersohn L, Last K, Tan S, Milan S, Tait D, and Smith IE Mortality within 30 days of chemotherapy: a clinical governance benchmarking issue for onocology patients. Br J Cancer 95, 1632-1636 (2006).

11 Torrisi JM, S. L., Gollub MJ, Ginsberg MS, Bosl GJ, Hricak H. CT Findings of Chemotherapy-induced Toxicity: What Radiologists Need to Know about the Clinical and Radiologic Manifestations of Chemotherapy Toxicity. Radiology 258, 41-56 (2011).

12 Orr GA, V.-P. P., McDaid H, Horwitz SB. Mechanisms of Taxol Resistance Related to Microtubules. Oncogene 22, 7280-7295 (2003).

13 Jordan, M. Mechanism of action of antitumor drugs that interact with microtubules and tubulin. Curr Med Chem Anticancer Agents 2, 1-17 (2002).

14 Eskey CJ, W. N., McDowell CL, Domach MM, Jain RK. Residence Time Distributions of Various Tracers in Tumors: Implications for Drug Delivery and Blood Flow Measurements. JNCI J Natl Cancer Inst 86, 293-299 (1994).

15 Rios-Doria J, C. A., Costich T, Burke B, Skaff H, Panicucci R, Sill. A Versatile Polymer Micelle Drug Delivery System for Encapsulation and In Vivo Stabilization of Hydrophobic Anticancer Drugs. Journal of Drug Delivery 2012 (2012).

16 Wang H, Y. Z. Molecular hydrogels of hydrophobic compounds: a novel self-delivery system for anti-cancer drugs. Soft Matter 8, 2344-2347 (2012).

17 Iijima, S. Helical microtubules of graphitic carbon. Nature 354, $56-58$ (1991).

18 Zhu HW, X. C., Wu DH, Wei BQ, Vajtai R, Ajayan PM. Direct synthesis of long singlewalled carbon nanotube strands. Science 296, 884-886, doi:10.1126/science.1066996 (2002). 
19 Thostenson, E. T. Advances in the science and technology of carbon nanotubes and their composites: a review. Composities Science and Technology 61, 1899-1912 (2001).

20 Hamada N. , S., S., and Oshiyama A. New one-dimensional conductors: Graphitic microtubules. Phys. Rev. Lett. 68, 1579-1581 (1992).

21 Mintmire JW, D. B., and White CT. Are fullerene tubules metallic? Phys. Rev. Lett. 68, 631-634 (1992).

22 Ruoff, R. Mechanical and thermal properties of carbon nanotubes. Carbon 33, 925-930 (1995).

23 Saito R, F. M., Dresselhaus G, and Dresselhaus MS. Physical Properties of Carbon Nanotubes. Phys. Rev. B: Condens. Matter Mater Phys. 46, 1804-1811 (1992).

24 Pampaloni F, F. E. Microtubule architecture: inspiration for novel carbon nanotube-based biomimetic materials. Trends in Biotechnology 26, 302-310 (2008).

25 Flavo MR, C. G., Taylor RM, Chi V, Brooks FP, Washburn S, Superfine R. Bending and buckling of carbon nanotubes under large strain. Nature 389, 582-584 (1997).

26 Lu, J. Elastic properties of carbon nanotubes and nanoropes. Phys. Rev. Lett. 79, 12971300 (1997).

27 Salvetat JP, B. A., Bonard JM, Bacsa RR, Kulik AJ, Stockli T, Burnham NA, Forro L. Elastic and shear moduli of single-walled carbon nanotube ropes. Phys. Rev. Lett. 82, 944-947 (1999).

28 Wong EW, S. P., Lieber CM. Nanobeam mechanics: elasticity, strength, and toughness of nanorods and nanotubes. Science 277, 1971-1975 (1997).

$29 \mathrm{Yu}, \mathrm{M}$. Fundamental mechanical properties of carbon nanotubes: current understanding and the related experimental studies. J. Eng. Mater. Technol. Transact. 126, 271-278 (2004).

30 Steinhogl W, S. G., Stinelesberger G, Traving M, Engelhardt. Comprehensive study of the resistivity of copper wires with lateral dimensions of $100 \mathrm{~nm}$ and smaller. $J$ Appli Phys 97, doi:http://dx.doi.org/10.1063/1.1834982 (2005).

31 Graham AP, D. G., Seidel R, Liebau M, Unger E, Krepul UF, Honlein W. Towards the integration of carbon nanotubes in microelectronics. Diamond and Related Materials 13, 1296-1300 (2004).

32 Bachtold A, H. P., Nakanishi T, Dekker C. Logic Circuits with Carbon Nanotube Transistors. Science 294, 1317-1320 (2001).

33 Derycke V, M. R., Appenzeller J, Avouris P Carbon Nanotube Inter-and Intramolecular Logic Gates. Nano Lett 1, 453-456 (2001).

34 Fuhrer MS, K. B., Durkop T, Brintlinger. High-Mobility Nanotube Transistor Memory. Nano Lett 2, 755-759 (2002).

35 Claye AS, F. J., Huffman CB, Rinzler AG, Smalley RE Solid-state electrochemistry of the Li single wall carbon nanotube system. J Electrochem Soc 147, 2845-2852 (2000).

36 Leroux F, M. S., Gautier E, Frackowiak S, Bonnamy S, Beguin F. Electrochemical insertion of lithium in catalytic multi-walled carbon nanotubes. J Power Sources 81, 317322 (1999).

$37 \mathrm{Lu} \mathrm{W}, \mathrm{C}$. D. Anodic performance of vapor-derived carbon filaments in lithium-ion secondary battery. Carbon 39, 493-496 (2001).

38 Shimoda H, G. B., Tang XP, Kleinhammes A, Fleming L, Wu Y, Zhou O. Lithium intercalation into opened single-wall carbon nanotubes: storage capacity and electronic properties. Phys. Rev. Lett. 88 (2002). 
39 Kelly, A. Composite Material after Seventy Years. J Mater Sci 41, 905-912 (2006).

40 Rohatgi, P. Cast aluminum-matrix composites for automotive applications. JOM 43, 1015 (1991).

41 Rawal, S. Metal-Matrix Composites for Space Applications. JOM 53, 14-17 (2001).

42 Shelly JS, L. R., Nichols J. Metal-Matrix Composites for Liquid Rocket Engines. JOM 53, 18-21 (2001).

43 Fan Z, L. G., Zhang Z, Zhou L, Wei. Electromagnetic and microwave absorbing properties of multi-walled carbon nanotubes/polymer composites. Materials Science and Engineering: B 132, 85-89 (2006).

44 Gibson RF, A. E., Wen YF. Vibrations of carbon nanotubes and their composites: A review. Compos Sci Technol 67, 1-28 (2007).

45 Suhr J, K. N., Keblinski P, Ajayan PM. Viscoelasticity in carbon nanotube composites. Nature Mater 4, 134 (2005).

46 Suhr J, Z. W., Ajayan PM, Koratkar NA. Temperature-activated interfacial friction damping in carbon nanotube polymer composites. Nano Lett 6, 219-223 (2006).

47 Endo M, K. S., Matsuda Y, Hayashi T, Kim YA. Thrombogenicity and blood coagulation of a micro-catheter prepared from carbon nanotube-nylon based composite. Nano Lett 5, 101-106 (2005).

48 Lacerda, L. Carbon nanotube cell translocation and delivery of nucleic acids in vitro and in vivo. J. Mater. Chem 18, 17-22 (2008).

49 Li X, P. Y., Qu X. Carbon nanotubes selective destabilization of duplex and triplex DNA and inducing B-A transition in solution. Nucleic Acids Research 34, 3670-3676 (2006).

50 Dinu CZ, B. I., Bale SS, Campbell AS, Kane RS, Dordick JS. Perhydrolase-nanotubepaint sporicidal composites stabilized by intramolecular crosslinking. Journal of Molecular Catalysis B: Enzymatic 75, 20-26 (2012).

51 Dinu CZ, Z. G., Bale SS, Anand G, Reeder PJ, Sanford K, Whited G, Kane RS, Dordick JS. Enzyme-Based Nanoscale Composites for Use as Active Decontamination Surfaces. Advanced Functional Materials 20, 392-398 (2010).

52 Dinu CZ, B. S., Zhu G, and Dordick JS. Tubulin Encapsulation of Carbon Nanotubes into Functional Hybrid Assemblies. Small x, 1-6 (2009).

53 Huh YM, J. Y., Song HT, Kim S, Choi JS, Lee JH, Yoon S, Kim KS, Shin JS, Suh JS. In vivo magnetic resonance detection of cancer by using multifunctional magnetic nanocrystals. J Am Chem Soc 127, 12387-12391 (2005).

54 Robinson JT, H. G., Liang Y, Zhang B, Yaghi OK, Dai H. In Vivo Fluoresence Imaging in the Second Near-Infrared Window with Long Circulating Carbon Nanotubes Capable of Ultrahigh Tumor Uptake. J Am Chem Soc 134, 1066410669 (2012).

55 Ramachandran S, E. K., Bachand GD, Vogel V, Hess H. Selective loading of kinesinpowered molecular shuttles with protein cargo and its application to biosensing. Small 2, 330-334 (2006).

56 Yinghuai Z, P. A., Carpenter K, Maguire JA, Hosmane NS, Takagaki M. Substituted caborane-appended water soluable single-walled carbon nanotubes: New approach to boron neutron capture therapy drug delivery. J Am Chem Soc 127, 9875-9880 (2005).

57 Taira S, D. Y., Hiratsuka Y, Uyeda TQ, Yumoto N, Kodaka M Loading and unloading of molecular cargo by DNA-conjugated microtubule. Biotechnol Bioeng 99, 734-739 (2008). 
58 Omidi, Y. CNT Nanobombs for Specific Eradication of Cancer Cells: A New Concept in Cancer Theranostics. BioImpacts 1, 199-201, doi:doi: 10.5681/bi.2011.028 (2011).

59 Shi J, C. T., Claussen JC, Diggs AR. Microbiosensors based on DNA modified singlewalled carbon nanotube and Pt black nanocomposites. Analyst 136, 4916-4924 (2011).

60 Khandare JJ, J.-B. A., Satavalekar SD, Bhansali SG, Aher ND, Kharas F, Banerjee SS. PEG-conjugated highly dispersive multifunctional magnetic multi-walled carbon nanotubes for cellular imaging. Nanoscale 4, 837-844 (2012).

61 Cherukuri P, B. S., Litovsky SH, Weisman RB. Near-infared fluorescence microscopy of single-walled carbon nanotubes in phagocytic cells. J Am Chem Soc 126, 15638-15639 (2004).

62 Pan D, C. J., Yao S, Tao W, Nie L. An Amperometric Glucose Biosensor Based on Glucose Oxidase Immobilized in Electropolymerized Poly(o-aminopheiol) and Carbon Nanotubes Composite Film on a Gold Electrode. Analytical Sciences 21, 367-371 (2005).

63 Gao A, A. A., Trigg AD, Singh N, Fang C, Tung CH, Fan Y, Buddharaju KD, Kong J. Accumulation mode field-effect transistors for improved sensitivity in nanowire-based biosensors. Anal. Chem. 79, 3291-3297 (2007).

64 Hahm J, L. C. Direct Ultrasensitive Electrical Detection of DNA and DNA Sequence Variations Using Nanowire Nanosensors. Nano Lett 4, 51-54 (2004).

65 Kurkina T, V. A., Ahmad A, Kern K, Balasubramanian K. Label-Free Detection of Few Copies of DNA with Carbon Nanotube Impedance Biosensors. Angew Chem Int Ed 50, 3710-3714 (2011).

66 Liao H, P. B., Sitharaman B, Wang Y. Applications of carbon nanotubes in biomedical studies. Biomedical Nanotechnology: Methods adn Protocols, Methods in Molecular Biology 726, 223-241 (2011).

67 Wu HC, C. X., Liu L, Zhao F, Zhao Y. Chemistry of Carbon Nanotubes in Biomedical Applications. Journal of Materials Chemistry 20, 1036-1052 (2010).

68 Jain S, S. S., Pillai S. Toxicity Issues Related to Biomedical Applications of Carbon Nanotubes. J Nanobed Nanotechol 3, 1000140 (2012).

69 Doak SH, G. S., Manshian B, Singh N, Williams PM, Brown AP, Jenkins GJ. Confounding experimental considerations in nanogenotoxicology. Mutagenesis 24, 285293 (2009).

70 Aitken RJ, C. M., Boxall AB, and Hull M. Manufacture and use of nanomaterials: Current status in the UK and global trends Occup Med (Lond) 56, 300-306 (2006).

71 Han JH, L. E., So KP, Lee YH, Bae GN, Lee SB, Ji JH, Cho MN, Yu IJ. Monitoring multiwalled carbon nanotube exposure in carbon nanotube research facility. Inhal Toxicol 20, $741-749$ (2008).

72 Maynard AD, B. P., Foley M, Shvedova AA, Kisin ER, Castranova V. Exposure to carbon nanotube material: Aerosol release during the handling of unrefined single-walled carbon nanotube material. J Toxicol Environ Health A 67, 87-107 (2004).

73 Yeganeh B, K. C., Hull MS, Marr LC. Characterization of airborne particles during production of carbonaceous nanomaterials. Environ Sci Technol 42, 4600-4606 (2008).

74 Pauluhn, J. Subchronic 13-week inhalation exposure of rats to multiwalled carbon nanotubes: Toxic effects are determined by density of agglomerate structures, not fibrillar structures. Toxicol Sci 113, 226-242 (2010). 
75 Muller J, H. F., Moreau N, Misson P, Heiler JF, Delos M, Arras M, Fonseca A, Nagy JB, Lison D. Respiratory toxicity of multi-walled carbon nanotubes Toxicol. Appl. Pharmacol. 207, 221-231 (2005).

76 Porter DW, H. A., Mercer RR, Wu N, Wolfarth MG, Sriram K, Leonard SS, Batelli L, Schwegler-Berry D, Friend S, Andrew M, Chen BT, Tsuruoka S, Endo M, Castranova V. Mouse pulmonary dose and time course-responses induced by exposure to multiwalled carbon nanotubes. Toxicology 269, 136-147 (2010).

77 Shvedova AA, K. E., Mercer R, Murray AR, Johnson VJ, Potapovich AI, Tyurina YY, Gorelik O, Arepalli S, Schwegler-Berry D, Hubbs AF, Antonini J, Evans DE, Ku BK, Ramsey D, Maynard A, Kagan VE, Castranova V, Baron P. Unusual inflammatory and fibrogenic pulmonary responses to single-walled carbon nanotubes in mice Am J Physiol: Lung Cell Mol Physiol 289, L698-708 (2005).

78 Shvedova AA, K. E., Murray AR, Johnson VJ, Gorelik O, Arapalli S, Hubbs AF, Mercer RR, Keohavong P, Sussman N, Jin J, Stone S, Chen B, Deye G, Maynard A, Castranova $\mathrm{V}$, Baron PA, Kagan V. Inhalation versus aspiration of single walled carbon nanotubes in C57BL/6 mice: inflammation, fibrosis, oxidative stress and mutagenesis. Am J Physiol Lung Cell Mol Physiol 295, L552-565 (2008).

79 OSHA. Limits for Air Contaminates: Occupational Safety and Health Standards, . Occupational Safety and Health Administration (2006).

80 Nanofibers, N. C. I. B. O. E. t. C. N. a. (2010 draft).

81 Mercer RR, H. A., Scabilloni JF, Wang L, Battelli LA, Friend S, Castranova V, Porter DW. Pulmonary fibrotic response to aspiration of multi-walled carbon nanotubes. Particle and Fibre Toxicology 8, 2-11 (2011).

82 Mercer RR, S. J., Wang L, Kisin E, Murray AR, Schwegler-Berry D, Shvedova AA, Castranova V. Alteration of deposition pattern and pulmonary response as a result of improved dispersion of aspirated single-walled carbon nanotubes in a mouse model. Am J Physiol Lung Cell Mol Physiol 294, L87-L97 (2008).

83 Porter DW, W. M., Chen BT, McKinney W, Hubbs AF, Batelli L, Andrews M, Frazer D, Castranova V. Pulmonary toxicity of inhaled multi-walled carbon nanotubes. The Toxicologist 108 (2009).

84 Takagi A, H. A., Nishimura T, Fukumori N, Ogata A, Ohashi N. Induction of mesothelioma in $\mathrm{p} 53+/-$ mouse by intraperitoneal application of multi-walled carbon nanotube. J Toxicol Sci 33, 105-116 (2008).

85 Schins, R. Mechanisms of genotoxicity of particles and fibers. Inhal Toxicol 14, 57-78 (2002).

86 Raja PMV, C. J., Ganesan GP, Lijie C, Ajayan PM, Nalamasu O, Thompson DM. Impact of carbon nanotube exposure, dosage and aggregation on smooth muscle cells. Toxicology Letters 169, 51-63 (2007).

87 Bardi G, T. P., Ciofani G, Raffa V, Costa M, Pizzorusso T. Pluronic-coated carbon nanotubes do not induce degeneration of cortical neurons in vivo and in vitro. Nanomedicine 5, 96-104 (2009).

88 Pantarotto D, S. R., McCarthy D, Erhardt M, Briand JP, Prato M, Kostarelos K, Bianco A. Functionalized carbon nanotubes for plasmid DNA gene delivery. Angew Chem Int Ed Engl 43, 5242-5246 (2004). 
89 Shi Kam NW, J. T., Wender PA, Dai H. Nanotube molecular transporters: internalization of carbon nanotube-protein conjugates into mammalian cells. J Am Chem Soc 126, 68506851 (2004).

90 Vittorio O, R. V., Cuschieri A. Influence of purity and surface oxidation on cytotoxicity of multiwalled carbon nanotubes with human neuroblastoma cells. Nanomedicine: Nanotechnology, Biology, and Medicine 5, 424-431 (2009).

91 Donaldson K, T. C. Inflammation caused by particles and fibers. Inhal Toxicol I 4, 5-27 (2002).

92 Muller J, D. M., Panin N, Rabolli V, Huaux F, Lison D. Absence of Carciongenic Response to Multiwalled Carbon Nanotubes in 2-Year Bioassay in the Peritoneal Cavity of the Rat. Toxicological Sciences 110, 442-448 (2009).

93 Muller J, D. I., Hoet PH, Lombaert N, Thomassen L, Huaux F, Lison D, and KirshVolders M. Clastogenic and aneugenic effects of multi-walled carbon nanotubes in epithelial cells Carcinogenesis 29, 427-433 (2008).

94 Sargent LM, S. A., Hubbs AF, Salisbury JL, Benkovic SA, Kashon ML, Lowry DT, Murray AR, Kisin ER, Friend S, McKinstry KT, Battelli L, and Reynolds SH. Induction of Aneuploidy by Single-Walled Carbon Nanotubes Environmental and Molecular Mutagenesis 50, 708-717 (2009).

95 Liu D, W. L., Wang Z, Cuschieri A. Different cellular response mechanisms contribute to the length-dependent cytotoxicity of multi-walled carbon nanotubes. Nanoscale Research Letters 7, 361-371 (2012).

96 Pacurari M, Y. X., Zhao H, Ding M, Leonard SS, Schwegler-Berry D, Ducatman BS, Sbarra D, Hoover MD, Castranova V, Vallyathan V. Raw Single-Wall Carbon Nanotubes Induce Oxidative Stress and Activate MAPKs, AP-1, NF-kB, and Akt in Normal and Malignant Human Mesothelial Cells. Environmental Health Perspectives 116, 1211-1217 (2008).

97 Ding L, S. J., Zhang T, Elboudwarej O, Jiang H, Selegue JP, Cooke PA, Gray JW, Chen FF. Molecular Characterization of the Cytotoxic Mechanism of Multiwall Carbon Nanotubes and Nano-Onions on Human Skin Fibroblast. Nano Lett 5, 2448-2464 (2005).

98 Guo N, W. Y., Denvir J, Porter DW, Pacurari M, Wolfarth MG, Castranova V, and Qian Y. Multi-walled carbon nanotube-induced gene signatures in the mouse lung: potential predictive value for human lung cancer risk and prognosis. J Toxicol Environ Health A 75, 1129-1153 (2012).

99 Haniu H, S. N., Matsuda Y, Kim YA, Park KC, Tsukahara T, Usui Y, Aoki K, Shimizu M, Ogihara N, Hara K, Takanashi S, Okamoto M, Ishigaki N, Nakamura K, Kato H. Effects of dispersants of multi-walled carbon nanotubes on cellular uptake and biological responses. International Journal of Nanomedicine 6, 3295-3307 (2011).

100 Kisin ER, M. A., Sargent LM, Lowry DT, Chirila M, Siegrist KJ, Schwegler-Berry D, Leonard S, Castranova V, Fadeel B, Kagan VE, and Shvedova AA. Genotoxicity of carbon nanofibers: Are they potentially more or less dangerous than carbon nanotubes or asbestos? Toxicology and Applied Pharmacology 252, 1-10 (2011).

101 Lindberg HK, F. G., Suhonen S, Vippola M, Vanhala E, Catalan J, Savolainen K, Norppa H. Genotoxicity of nanomaterials: DNA damage and micronuclei induced by carbon nanotubes and graphite nanofibers in human bronchila epithelial cells in vitro. Toxicol Lett 186, 166-173 (2009). 
102 Cavallo D, F. C., Ursini CL, Casciardi S, Paba E, Ciervo A, Fresegna AM, Maiello R, Marcelloni AM, Buresti G, Tombolini F, Bellucci S, Iavicoli S. Multi-walled carbon nanotube induce cytotoxicity and genotoxicity in human lung epithelial cells. $J$ Appl Toxicol 32, 454-464 (2011).

103 Ursini CL, C. D., Fresegna AM, Ciervo A, Maiello R, Buresti G, Casciardi S, Tombolini F, Bellucci S, Iavicoli S. Comparative cyto-genotoxicity assessment of functionalized and pristine multiwalled carbon nanotubes on human lung epithelial cells. Toxicology In Vitro 26, 831-840 (2012).

104 Reilly, R. Carbon Nanotubes: Potential Benefits and Risks of Nanotechnology in Nuclear Medicine. J Nucl Med 48, 1039-1042 (2007).

105 Sargent LM, H. A., Young SH, Kashon ML, Dinu CZ, Salisbury JL, Benkovic SA, Lowry DT, Murray AR, Kisin ER, Siegrist KJ, Battelli L, Mastovich J, Sturgeon JL, Bunker KL, Shvedova AA, Reynolds SH. Single-walled carbon nanotube-induced mitotic disruption. Mutation Research 745, 28-37 (2012).

106 Rodriguez-Fernandez L, V. R., Gonzalez J, Villegas JC, Fanarraga ML. Multiwalled carbon nanotubes display microtubule biomemetic properties in vivo, enhancing microtubule assembly and stabilization. ACS Nano 6, 6614-6625 (2012).

107 Nakai R, I. S., Takahashi T, Tsujita T, Okamoto S, Takada C, Akasaka K, Ichikawa S, Ishida H, Kusaka H, Akinaga S, Murakata C, Honda S, Nitta M, Saya H, Yamashita Y. K858, a Novel Inhibitor of Mitotic Kinesin Eg5 and Antitumore Agent, Induces Cell Death in Cancer Cells. Cancer Res 69, 3901-3909 (2009).

108 Hut HM, L. W., Blaauw EH, Van Cappellen GW, Kampinga HH, Sibon OC. Centrosomes split in the presence of impared DNA integrity during mitosis. Mol Biol Cell 14, 1993-2004 (2003).

109 Abal M, K. G., Bornens M. Centrioles resist forces applied on centrosomes during G2/M transition. Biol Cell 97, 425-434 (2005).

110 Krzysiak TC, W. L., Sproul P, Tittmann H, Gross SP, Gilbert A, Hoenger A. A structural model for monastrol inhibition of dimeric kinesin Eg5. EMBO J 25, 2263-2273 (2006).

111 Cooper, G. The Cell: A Molecular Approach. 2nd edn, (2000).

112 Amos, L. Focusing-in on microtubules. Curr Opin Struct Biol 10, 236-241 (2000).

113 Hyams JS, L. C. Microtubules. ( Wiley-Liss, 1994).

114 Ludvena, R. The multiple forms of tubulin: different gene products and covalent modifications. Int Rev Cytol 178, 207-275 (1998).

115 Nogales, E. Structural insight into microtubule function Annu Rev Biophys Biomol Struct 30, 397-420 (2001).

116 Burbank KS, M. T. Quick Guides: Microtubule dynamic instability. Current Biology 16, R516, doi:doi:10.1016/j.cub.2006.06.044 (2006).

117 Mardin BR, S. E. Breaking the ties that bind: New advances in centrosome biology. $J$ Cell Biol 197, 11-18 (2012).

118 Tanenbaum ME, M. R. Mechanisms of centrosome separation and bipolar spindle assembly. Dev Cell 19, 797-806 (2010).

119 Cytrynbaum EN, S. P., Brust-Mascher I, Scholey JM, Mogilner A. Early spindle assembly in Drosophilia embryos: role of a force balance involving cytoskeletal dynamics and nuclear mechanics. Mol Biol Cell 16, 4967-4981 (2005).

120 Manning CB, V. V., Mossman BT. Diseases caused by asbestos: mechanisms of injury and disease development. Int Immunopharmacol 2, 191-200 (2002). 
121 Shukla A, C. M., Hei TK, Kamp D, Rahman Q, Mossman BT. Multiple roles of oxidants in the pathogenesis of asbestos-induced diseases. Free Radic Biolo Med 34, 117-1129 (2003).

122 Nam CW, K. S., Kwak MK. Cell growth inhibition and apoptosis by SDS-solubilized single-walled carbon nanotubes in normal rat kidney epithelial cells. Arch Pharm Res 34, 661-669 (2011).

123 Zhang Y, Y. B. Cell Cycle Regulation by Carboxylated Multiwalled Carbon Nanotubes through p53-Independant Induction of p21 under the Control of the BMP Signaling Pathway. Chem Res Toxicol 26, 1212-1221 (2012).

124 Tong L, Z. W., Hang H, Yu Z, Chu PK, Xu A. Toxicity of carbon nanotubes to p21 and hus1 gene deficient mammalian cells. J Nanosci Nanotechnol 11, 11001-11005 (2011).

125 Dinz CZ, B. S., Dordick JS. Kinesin 1 ATPase manipulates biohybrids formed from tubulin and carbon nanotubes. Methods Mol Biol 743, 77-93 (2011).

126 Pecreaux J, R. J., Kruse K, Julicher F, Hyman AA, Grill SW, Howard J. Spindle oscillations during asymmetric cell division require a threshold number of active cortical force generators. Curr biol 16, 2111-2122 (2006).

127 Alberts B, J. A., Lewis J, Raff M, Roberts K, and Walter P. in Molecular Biology of the Cell (Garland Science, 2002).

128 Lodish H, B. A., Zipursky SL, et al. in Molecular Cell Biology (W. H. Freeman, 2000).

129 Howard, J. Mechanical Signaling in Networks of Motors and Cytoskeletal Proteins. Annu Rev Biophys 38, 217-234 (2009).

130 Howard J, H. A. Dynamics and mechanics of the microtubule plus end. Nature 422, 753758 (2003).

131 Burakov A, K. O., Semenovva I, Zhaparova O, Nadezdina E, Rodionov V. Cytoplasmic Dynein is Involved in the Retention of Microtubules at the Centrosome in Interphase. Traffic 9, 472-480 (2008).

132 Busson S, D. D., Moreau A, Dompierre J, and De Mey JR. Dynein and dynactin are localized to astral microtubules and at cortical sites in mitotic epithelial cells. Curr Biol 8, 541-544 (1998).

133 Dujardin DL, V. R. Dynein at the cortex. Curr Opin Cell Biol 14, 44-49 (2002).

134 Quintyne NJ, S. T. Distinct cell cycle-dependant roles for dynactin and dynein at centrosomes. Journal of Cell Biology 159, 245-254 (2002).

135 Tanenbaum ME, M. L., Galjart N, Medema RH. Dynein, Lis1 and CLIP-170 counteract Eg5-dependdant centrosome separation during bipolar spindle assembly EMBO J 27, 3235-3245 (2008).

136 Salisbury, J. Breaking the ties that bind centriole numbers. Nat Cell Biol 10, 255-257 (2008).

137 Salisbury JL, D. A. A., Lingle WL. Centrosome amplification and the origin of chromosomal instability in breast cancer. J Mammary Gland Biol Neoplasia 9, 275-283 (2004).

138 Ferenz NP, P. R., Fagerstrom C, Mogilner A, Wadsworth P. Dynein Antagonizes Eg5 by Crosslinking and Sliding Antiparallel Microtubules Curr Biol 19, 1833-1838 (2009).

139 Gable A, Q. M., Titus H, Balchand S, Ferenz NP, Ma N, Collins ES, Fagerstron C, Ross JL, Yang G, Wadsworth P. Dynamic reorganization of Eg5 in the mammalian spindle throughout mitosis requires dynein and TPX2. Mol Biol Cell 23, 1254-1266 (2012). 
140 Raajimakers JA, v. H. R., Meaders JL, Geers EF, Fernandez-Garcia B, Medema RH, Tenebaum ME. Nuclear envelope-associated dynein drives prophase centrosome separation and enables Eg5-independent bipolar spindle formation. The EMBO Journal 31, 4179-4190 (2012).

141 Cole DG, S. W., Sheehan KB, Scholey JM. A "slow" homotetrameric kinesin-related motor protein purified from Drosophilia embryons. J Biol Chem 269, 22913-22916 (1994).

142 Kapitein LC, P. E., Kwok BH, Kim JH, Kapoor TM, Schmidt CF. The bipolar mitotic kinesin Eg5 moves on both microtubules that it crosslinks. Nature 435, 114-118 (2005).

143 Le Guellec R, P. J., Courturier A, Le Guellec K, Roghi C, Philippe M. Cloning by differential screening of a Xenopus cDNA that encodes a kinesin-related protein. Mol Cell Biol 11, 3395-3398 (1991).

144 Sharp DH, M. K., Brown HM, Matthies HJ, Walczak C, Vale RD, Mitchison TJ, Scholey JM. The bipolar kinesin, KLP61F cross-links microtubules within interpolar microtubule bundles of Drosophiliz embryonic mitotic spindles. J Cell Biol 144, 125-138 (1999).

145 Swain KE, L. K., Philippe M, Mitchison TJ. Mitotic spindle organization by a plus-enddirected microtubule motor. Nature 359, 540-543 (1992).

146 Blangy A, A. L., Nigg EA. Phosphorylation by p34 ${ }^{\text {cdc2 }}$ Protein Kinase Regulates Binding of the Kinesin-related Motor HsEg5 to Dynactin Subunit $\mathrm{p} 150^{\text {Glued }}$. The Journal of Biological Chemistry 272, 19418-19424 (1997).

147 Blangy A, L. H., d'Herin P, Harper M, Kress M, Nigg EA. Phosphorylation by p34 ${ }^{\text {cdc2 }}$ Regulates Spindle Association of Human Eg5, a Kinesin-Related Motor Essential fo Bipolar Spindle Formation In Vivo. Cell 83, 1159-1169 (1995).

148 Fink G, H. L., Skowronek KJ, Reuther C, Kasprzak AA, Diez S. The mitotic kinesin-14 Ncd drives directional microtubule-microtubule sliding Nat Cell Biol 11, 717-723 (2009).

149 Verhey KJ, H. J. Traffic control: regulation of kinesin motors. Nature Reviews Molecular Cell Biology 10, 765-777 (2009).

150 Cahu J, O. A., Hentrich C, Schek H, Drinjakovic J, Zhang C, Doherty-Kirby A, Lajoie G, Surrey T. Phosphorylation by Cdk1 Increases the Binding of Eg5 to Microtubules In Vitro and in Xenopus Egg Extract Spindles. PLoS ONE 3, e3936 (2008).

151 Bartoli KM, J. J., Woolford JL, Saunders WS. Kinesin molecular motor Eg5 functions during polypeptide synthesis. Mol Biol Cell 22, 3420-3430 (2011).

152 Chen Y, C. J., Poon RYC. Inhibition of Eg5 Acts Synergistically with Checkpoint Abrogatin in Promotic Mitotic Catastrophe. Mol Cancer Res 10, 626-635 (2012).

$153 \mathrm{Ng}$ CT, L. J., Bay BH, Yung LYL. Current Studies into the Genotoxic Effects of Nanomaterials. Journal of Nucleic Acids 2010, doi:doi:10.4061/2010/947859 (2010).

154 Castillo A, M. H., Godfrey VL, Naeem R, Justice MJ. Overexpression of Eg5 Causes Genomic Instability and Tumore Formation in Mice. Cancer Res 67, 10138-10147 (2007). 


\title{
Chapter 2
}

\section{Changes in the Eg5 and Dynein Expression Profiles following Exposure of Epithelial Cells to Multiwalled Carbon Nanotube}

\begin{abstract}
:
Carbon nanotubes (CNTs) have been studied for their potential use in cellular delivery of molecules, drugs and RNA. However, contradictory reports on CNTs toxicity make such applications questionable. Recent studies have shown that upon exposure, CNTs associate with cellular elements, namely the cytoskeletal filament microtubules and DNA, and interfere with the cell progression through normal division most notably by disruption of the centrosome. We hypothesized that CNTs could induce changes in the expression level of the CNTs-treated BEAS2B human airway epithelial cells, which we used as a model system. Such changes are correlated with changes in the cell cycle progression and draw a parallel relationship with the nanomaterial properties, both physical and chemical. It is anticipated that DNA damage is augmented by interactions of CNTs with the molecular motors and microtubules leading to cell cycle arrest in the G1/S phase. We found that occupational exposure doses induced down regulation in the expression level of key molecular motors involved in cell division, thus representing a newly recognized mechanism by which CNTs may modulate epithelial cell responses germane to genotoxicity and tumorigenesis. We propose that the mechanism involves alterations in the forces responsible for the mitotic spindle formation thus implicating $a$ mechanical imbalance. Such interference could lead to aneuploidy and tumorigenesis.
\end{abstract}

Keywords: mitotic spindle, Eg5, dynein, genotoxicity, functionalized, MWCNT, cell cycle, in vitro

\section{Introduction:}

Normal progression through the cell cycle is critical for the maintenance of cellular division, protein expression and cell viability ${ }^{1-3}$. Cell cycle is regulated through a series of checkpoint responses; efforts to modulate the cell cycle are required to ensure the quality and 
rate of cell division. Generally, the loss of cell cycle checkpoint responses has been reported to lead to propagation of unequal chromosomes, irreversible genetic disturbances, and initiation of tumorigenesis $^{1,4}$. Further, lack of reliability in cellular DNA replication or in the maintenance of the cell cycle and responsible proteins involved with cell cycle progression, can result in deleterious mutations leading to genotoxic stress ${ }^{5}$, cell death ${ }^{6,7}$, or initiation of cancer ${ }^{1,4}$.

Changes in the cell cycle have been reported upon cellular exposure to nanomaterials ${ }^{8-12}$ such as silver nanoparticles ${ }^{13}$, silica ${ }^{14}$, or titanium dioxide nanoparticles ${ }^{15}$. In particular, carbon-based materials such as carbon nanotubes (CNTs), fullerenes (C60) and carbon nanofibers (CNF) have been shown to cause cellular aneuploidy ${ }^{10,16-18}$ and induce cell cycle arrest $^{8-12}$ in a dose- dependent manner ${ }^{10}$. Cellular exposure to CNTs, members of the fullerene family and allotropes of carbon ${ }^{19-21}$, known for their inherent mechanical ${ }^{22-26}$, electrical ${ }^{27-33}$, optical ${ }^{34-36}$ and thermal ${ }^{24}$ properties that make them viable candidates for applications in engineering 37,38 and bio-medical sectors ${ }^{35,39-44}$, have been shown to lead to initiation of tumorigenesis through cell cycle disturbances ${ }^{8-12,17}$. In vitro treatment with multi-walled carbon nanotubes (MWCNTs), comprised of multiple sheets of $\mathrm{sp}^{2}$ hybridized carbon atoms rolled into a cylinder with concentric layers held together by secondary van der waals interactions ${ }^{19-21,24,30-}$ 32,45,46, showed cell cycle changes to HeLa cells in culture ${ }^{9}$. A drop in the G1 phase and an increase in cells at the S/G2 phase border, indicative of a cell cycle check-point response, as well as MWCNTs impaired normal progression through cellular division were observed ${ }^{9}$. In agreement with these findings, Zhang et al., have showed that treatment with carboxylated MWCNTs led to up regulation of cyclin dependant kinase inhibitor 1 (p21), a known inhibitor of the cell cycle, following impaired bone morphogenic protein initiation (BMP) ${ }^{12}$. Such damages caused by the MWCNTs treatment led to irreversible genetic mis-segregation 1,4,47. Further, studies have reported micronuclei formation via comet assay that confirmed breakage of DNA 9,48-51 and pan-centromeric staining ${ }^{10,16,18}$, which is indicative of breakage and/or disruption of the mitotic spindle apparatus. These findings combined with evidence of disturbed cell cycle regulation ${ }^{12}$ illuminate part of the primary genotoxic pathways elicited following MWCNT exposure. However, of the scientific reports that are currently published there seems to be an incongruence of professional opinion in the area of CNT-induced genotoxicity ${ }^{52}$. Namely, these conflicting reports are mainly due to the lack of experimental consistency associated with the 
CNT manufacturer, uncertain composition, purity and functionality, and exposure dose used in the experiments meant to elicit such toxic pathways.

Here, we report a detailed study on the potential molecular mechanisms underlying MWCNTs genotoxicity. In particular, we hypothesized that the changes in the cell cycle are associated with changes in the mRNA expression of integral molecular motor proteins, dynein and Eg5, involved in the cell division process. Further, we hypothesized that these changes are correlated to the cell progression through the cell cycle upon exposure to nanomaterials with different characteristics (i.e. physical and chemical properties). Human airway epithelial cells were used as a model system. In the cell, dynein and Eg5 ${ }^{53-62}$ control the dynamics of the spindle formation and help in even segregation of chromosomes ${ }^{63,64,65}$. Cytoplasmic dynein forms the dynein-dynactin complex ${ }^{54,61,66-69}$; dynein is a minus end directed molecular motor, responsible for the transportation of intracellular organelles along the cytoplasmic microtubule network ${ }^{70,71}$. Dynein localizes near the cell cortex ${ }^{68}$, along the plus ends of growing microtubules near the nuclear envelope ${ }^{72,73}$ or at the centrosomes where it helps with centrosome separation ${ }^{62,69,74-76}$ and organization of radial microtubule arrays ${ }^{54}$. Eg5 belongs to the kinesin-5 subclass of motor proteins and is a part of the Bim-C kinesin family ${ }^{77-81}$. Eg5 is a slow moving, plus end directed homotetrameric motor protein ${ }^{77-81}$ that localizes at the spindle poles ${ }^{53}$ and along the interpolar microtubule network. Eg5 attaches to antiparallel microtubules, and provides directional force required to separate the spindle ${ }^{65,77-82}$. Regulation of these molecular motors occurs in response to phosphorylation of cyclin dependant kinases (CDKs) $53,55,83$ i.e. cell cycle checkpoint regulators. Our data acquired using fluorescent activated cell sorting to quantify the DNA of the sorted cells, and real-time polymerase chain reaction to quantitatively measure the mRNA concentrations of the two molecular motors, provide a viable mechanical model to be associated with genotoxicity. Such expressional changes in integral molecular motor protein concentrations can result in mitotic catastrophe causing aneuploidy ${ }^{9,10,16,17}$, and the initiation of tumorigenesis, genotoxicity and cancer progression. ${ }^{47,84,85}$ 


\section{Materials and Methods:}

\section{Multi-walled carbon nanotubes (MWNCTs) acids oxidation}

Commercial multi-walled carbon nanotubes (MWNCTs) purchased from NanoLab Inc. (PD15L5-20, purity > 95\%) were acid oxidized. MWCNTs were incubated in a concentrated sulfuric (96.4\%, Fisher, USA) and nitric (69.5\%, Fisher, USA) acids mixture with a volume ratio of 3:1 as previously described ${ }^{86}$. The mixture was then placed on an ice bath in a sonicator for 1 or $3 \mathrm{~h}$ at a constant temperature of $23^{\circ} \mathrm{C}$. Subsequently, the mixture was diluted in $2 \mathrm{~L}$ of deionized (Di) water and filtered through a GTTP $0.2 \mu \mathrm{m}$ polycarbonate filter membrane (Fisher, USA). The procedure was repeated for several cycles to remove any acid traces. The MWCNTs isolated on the filter membrane were subsequently dried under the vacuum and stored at room temperature for future use.

\section{MWCNTs physical and chemical characterization}

Atomic force microscope (AFM) with Si tip (Asylum Research, 50-90 KHz AC240TS, USA) was used to quantify the length of pristine and acid oxidized MWCNTs. MCWNTs samples (1 and $3 \mathrm{~h}$ acids oxidized MWCNTs) were deposited on mica substrates $(9.5 \mathrm{~mm}$ diameter, 0.15- $0.21 \mathrm{~mm}$ thickness, Electron Microscopy Sciences, USA) for analysis. Scans of $10 \mu \mathrm{m} \times 10 \mu \mathrm{m}$ carried out in tapping mode were acquired. At least 30 individual MWCNTs from different images were collected for an average length distribution.

MWCNTs samples (both 1 and $3 \mathrm{~h}$ acids oxidized MWCNTs) were deposited on clean glass slides (Fisher Scientific, USA) for chemical structure investigation. Raman spectroscopy was performed using a Renishaw InVia Raman Spectrometer (CL532-100, 100 mW, USA) operating at room temperature and under an excitation wavelength of $514.5 \mathrm{~nm}$. The radiation was focused through a $20 \mathrm{X}$ objective for an area of $<0.01 \mathrm{~mm}^{2}$. Further, low energy (i.e., $<0.5$ $\mathrm{mV}$ ) and a short exposure time of only $10 \mathrm{sec}$ were employed to avoid unexpected heating effects of the samples. The scanned ranges were in between $100-3200 \mathrm{~cm}^{-1}$.

Energy dispersive R-ray spectroscopy (EDX) was employed for quantitative elemental analysis of the acid oxidized MWCNTs as previously described ${ }^{86}$. Briefly, the samples $(1 \mathrm{mg} / \mathrm{ml}$ in water, either 1 or $3 \mathrm{~h}$ acids oxidized MWCNTs) were placed on a silica substrate and dried 
under vacuum. A Hitachi S-4700 Field Emission Scanning Electron Microscope (USA) with an S-4700 detector, integrating secondary (SE) and backscattered (BSE) electron detection (in a single unit), was used to carry out the analysis at $20 \mathrm{kV}$. Data is represented as elemental weight percent.

MWCNTs sample solubility (either 1 or $3 \mathrm{~h}$ acids oxidized MWCNTs) was evaluated using a standard dispersity test ${ }^{86,87}$. Briefly, $3 \mathrm{mg}$ of MWCNTs were diluted in $1 \mathrm{~mL}$ of either DI water, phosphate buffered saline (PBS, Invitrogen, USA) or Dulbecco's Modified Eagle Media (DMEM, Invitrogen, USA) with 10\% Fetal Bovine Serum (FBS, HyClone, USA) and 1\% antimycotic and antibiotic supplement (Anti/Anti, GIBCO, USA). The over-concentrated MWCNTs suspension was centrifuged for $5 \mathrm{~min}$ at $3000 \mathrm{rpm}$; subsequently, $0.8 \mathrm{~mL}$ supernatant was removed and filtered through a $0.2 \mu \mathrm{m}$ GTTP filter membrane. The solubility of the MWCNTs was then calculated based on the difference between initial starting weight and final weight of the dispersed sample.

\section{Cell culture and treatment}

Immortalized human bronchial respiratory epithelial cells (BEAS-2B, ATCC, USA) of passage $<10$ were used to examine the potential toxicological effects of MWCNTs. Cells were cultured in DMEM media supplemented with $10 \% \mathrm{FBS}, 1 \%$ antimycotic and antibiotic at $37^{\circ} \mathrm{C}$, and $5 \% \mathrm{CO}_{2}$ flow.

For treatment, BEAS-2B cells were seeded in T-25 flasks (Corning, USA) at a cell density of $2 \times 10^{6}$ cells in $3 \mathrm{~mL}$ of culture media and allowed to achieve $70-85 \%$ confluency. Cell confluency and health was assessed using light microscopy (Olympus Optical Co., LTD, Japan) through a $20 \mathrm{X}$ objective, in bright field. Three independent replicates were exposed for $24 \mathrm{~h}$ to $0.24 \mu \mathrm{g} / \mathrm{mL}$ MWCNTs (either 1 or $3 \mathrm{~h}$ acids oxidized MWCNTs) diluted and sonicated in media for $1 \mathrm{~min}$ under $10 \mathrm{sec}$ pulse intervals delivered by a probe sonicator (Ultrasonic Processor 130W, 20kHz, Sonics \& Materials, Inc., USA). Following 24 h exposure, cells were recovered with fresh media and/or isolated or allowed to continue in culture for subsequent studies. 


\section{Fluorescent Assisted Cell Sorting (FACs)}

Following $24 \mathrm{~h}$ treatment, treated and control cells (not exposed to MWCNTs) were removed from T-25 flasks using $0.25 \%$ trypsin digestion (GIBCO, USA), pelleted by centrifugation at $1000 \mathrm{rpm}$ for $6 \mathrm{~min}$, resuspended in 1mL PBS, spun again at $1000 \mathrm{rpm}$ for 6 min and then resuspended in $200 \mu \mathrm{L}$ PBS. The resuspended cells were subsequently fixed in 2 $\mathrm{mL}$ of ice cold $70 \%$ biological grade ethanol (Sigma, USA) and stored at $-20^{\circ} \mathrm{C}$.

For Fluorescent Assisted Cell Sorting (FACs) analysis, fixed cells were pelleted at 1000 rpm for $6 \mathrm{~min}$. The ethanol was then decanted and cells were resuspended in $2 \mathrm{~mL}$ of PBS, incubated at room temperature for $60 \mathrm{sec}$, pelleted at $1000 \mathrm{rpm}$ for $6 \mathrm{~min}$, resuspended in $100 \mu \mathrm{L}$ of $0.2 \%$ Tween 20 (Sigma, USA) in PBS, and incubated for $15 \mathrm{~min}$ at $37^{\circ} \mathrm{C}$. Subsequently, 100 $\mu \mathrm{L}$ of PBSAz (PBS-Sodium Azide, Sigma USA, i.e. wash buffer comprised of PBS $+0.5 \% \mathrm{BSA}+0.02 \%$ Sodium Azide) was added to the cell suspension. Cells were again pelleted at $1000 \mathrm{rpm}$ for 6 min, resuspended in $10 \mu \mathrm{L}$ of RNaseA -PBS solution $(180 \mu \mathrm{g} / \mathrm{mL}$, Invitrogen, USA) per $5 \times 10^{5}-1 \times 10^{6}$ cells and incubated for $15 \mathrm{~min}$. Finally, $30 \mu \mathrm{L}$ of propidium iodide stain (final concentration $75 \mu \mathrm{g} / \mathrm{mL}$, Sigma, USA) per $5 \times 10^{5}-1 \times 10^{6}$ cells was added to the cell suspension followed by cell incubation on ice for 15-30 min.

FACS analyses were carried out using a FACsCalibur (BectonDickson, USA). 50,000 events were counted; all data was normalized to 30,000 events using FCS Express 4 Flow Cytometry software (De Novo Software, USA). Results are presented as \% of diploid cells in the G1, S or G2 phases.

\section{RNA isolation}

Cells exposed to MWCNTs for $24 \mathrm{~h}$ or the controls were lysed. Specifically, $1 \mathrm{~mL}$ RLT lysate buffer (included in RNeasy Mini Kit, Qiagen, USA) was mixed with $10 \mu \mathrm{L} \beta-\mathrm{Me}$ (Sigma, USA), and $700 \mu \mathrm{L}$ of this lysate was added per flask. Flasks were rocked briefly by hand to ensure efficient lysate buffer distribution and incubated for $10 \mathrm{~min}$. Flasks were next scraped with a cell scraper and the $700 \mu \mathrm{L}$ volume was removed using a pipette. Using RNeasy Qiashredder columns (Qiagen, USA) and RNeasy Mini kit (Qiagen, USA), RNA was isolated and purified according to manufacturer specifications. Also, a column DNase treatment was performed where $80 \mu \mathrm{L}$ of DNase I treatment per sample, i.e. $10 \mu \mathrm{L}$ of DNase I stock in $70 \mu \mathrm{L}$ of 
Buffer RDD (DNase I treatment kit, Qiagen, USA), was applied to the columns and incubated for $20 \mathrm{~min}$ at room temperature. Finally, RNA was eluted to a final elution volume of $30 \mu \mathrm{L}$ with nuclease free water. Microcentrifuge tubes containing the eluted total RNA were placed on ice. Absorbance was measured using the NanoDrop 2000 (THERMO Scientific, USA) blanked to nuclease free water. Absorbance readings were done in duplicates and averages were taken for cDNA synthesis calculations. RNA samples were stored at $-80^{\circ} \mathrm{C}$.

\section{RNA Quality Assessment}

RNA 260/230 absorbance readings of > 1.75 and 260/280 absorbance readings of > 1.9 and $<2.2$ were indicative of high integrity and quality samples ${ }^{88}$. Further quantitative analysis of the isolated RNA was carried out using the Bioanalyzer 2100 Agilent system (Agilent Technologies, Inc., USA) and software (Agilent Technologies, Inc., USA). Briefly, aliquots of isolated RNA were added to patented reagents, following manufacturer specifications; next, they were placed into the Agilent Eukaryote Total RNA Nano microchips and analyzed using the Bioanalyzer 2100. An RIN number $>7$ indicated high integrity RNA that was then used for cDNA synthesis and RT-PCR ${ }^{89}$.

\section{cDNA synthesis}

cDNA synthesis was performed in a $20 \mu \mathrm{L}$ reaction volume using the manufacturer directions for First Strand Synthesis System for RT-PCR (Invitrogen, USA). Oligo dT was used as a primer to achieve more consistent RT-PCR products ${ }^{90}$ and to provide more specific hybridization of the 3' poly(A) tails. Briefly, RNA template (1.5 $\mu \mathrm{g}$ per sample) and DEPCwater were added to Primer ( $1 \mu \mathrm{L}$ per sample) and dNTPs $(1 \mu \mathrm{L}$ per sample $)$ for a total volume of $10 \mu \mathrm{L}$ in $1.5 \mathrm{~mL}$ microcentrifuge tubes. Subsequently, the tubes were incubated in a $65^{\circ} \mathrm{C}$ water bath for $5 \mathrm{~min}$; upon incubation the tubes were removed and immediately placed on ice. Next, 10XRT buffer ( $2 \mu \mathrm{L}$ per sample), $25 \mathrm{mM} \mathrm{MgCl}_{2}$ ( $4 \mu \mathrm{L}$ per sample), $0.1 \mathrm{M}$ dithiothreitol (DTT) $(2 \mu \mathrm{L}$ per sample), RNaseOUT (40 U/ $\mu \mathrm{L}, 1 \mu \mathrm{L}$ per sample) and Superscript III RT (200 $\mathrm{U} / \mu \mathrm{L}, 1 \mu \mathrm{L}$ per sample) were added according to manufacturer specifications for a $20 \mu \mathrm{L}$ reaction volume, and the mixture was incubated in a $50^{\circ} \mathrm{C}$ water bath for $1 \mathrm{~h}$. All reagents were purchased from Invitrogen USA unless otherwise specified. Following the $1 \mathrm{~h}$ incubation, amplification was stopped by moving the tubes to a heating block at $85^{\circ} \mathrm{C}$ for $5 \mathrm{~min}$, and then 
placing tubes on ice. Finally, $1 \mu \mathrm{L}$ of RNase $\mathrm{H}$ was added to each tube and incubated at $37^{\circ} \mathrm{C}$ for $20 \mathrm{~min}$. Samples were diluted five times in nuclease free water and stored at $-20^{\circ} \mathrm{C}$.

\section{Standard Curve Method for Real time-polymerase chain reaction}

Real time-polymerase chain reaction (RT-PCR) was performed using the Applied Biosystems 7500 and 7900HT cycler systems (Applied Biosystems, USA). Taqman RT-PCR gene expression assays (Applied Biosystems, USA) were used, to ensure high quality detection. Briefly, cDNA was thawed on ice. Also placed on ice were Taqman Universal Master Mix and Taqman Gene Expression Assay Primers (Dynein-Hs00322286_m1 and Eg5-Hs0189698_m1, Applied Biosystems, USA) and nuclease free water. Components were added according to manufacturer specifications. Briefly, $5 \mu \mathrm{L}$ of cDNA, $1 \mu \mathrm{L}$ of primer, and $10 \mu \mathrm{L}$ of Taqman Universal Master Mix were added per well per sample for a reaction volume per well of $20 \mu \mathrm{L}$ adjusted with nuclease free water. Standard curves were established for each primer using pooled serially diluted PBS control cDNA. All reactions were carried out on a 96well reaction plate (Applied Biosystems, USA). The reaction plate was covered with a transparent and adherent plate film (Applied Biosystems, USA) and centrifuged at $1200 \mathrm{rpm}$ for 3 min prior running the experiment. For both the 7500 and 7900 cycler systems, relative quantifications were performed. Primers were selected and plate layout was designed as per software (Applied Biosystems, USA) requirements. The run was carried out under default settings adjusting for a $20 \mu \mathrm{L}$ reaction volume for a total of $1 \frac{1 / 2}{\mathrm{~h}}$. Auto CT was selected and data was analyzed using the RQ Manager Software package (Applied Biosystems, USA).

\section{Statistical analysis}

Data were analyzed using SAS software (North Carolina, USA), employing Mixed Procedure. F-tests for fixed effects and tables for least squared means were generated and analyzed for both FACs and RT-PCR procedures. Differences were evaluated using the TukeyKramer procedure, and p-values of 0.05 were considered significant. 


\section{$\underline{\text { Results: }}$}

\section{Multi-walled carbon nanotube physical and chemical characterization}

In the present study, two carboxylated multi-walled carbon nanotubes (MWCNTs) were prepared using oxidation with concentrated nitric and sulfuric acids for 1 and $3 \mathrm{~h}$ respectively. The resulting average length of the MWCNTs was determined using atomic force microscopy (AFM) and tapping mode. As shown in Figure 1A, the analyses revealed an average length of $903 \pm 368 \mathrm{~nm}$ and $616 \pm 344 \mathrm{~nm}$ for the 1 and $3 \mathrm{~h}$ acids oxidized MWCNTs respectively. The shift towards shorter lengths observed for the $3 \mathrm{~h}$ acids oxidized MWCNTs is in agreement with previous reports that showed that acids mixture reacts with the $\mathrm{C}-\mathrm{C}$ band of the nanotube graphene sheets and induces oxidization and functionalization of nanotubes at defects site along their side walls, thus generating shorter nanotubes ${ }^{86,91}$.

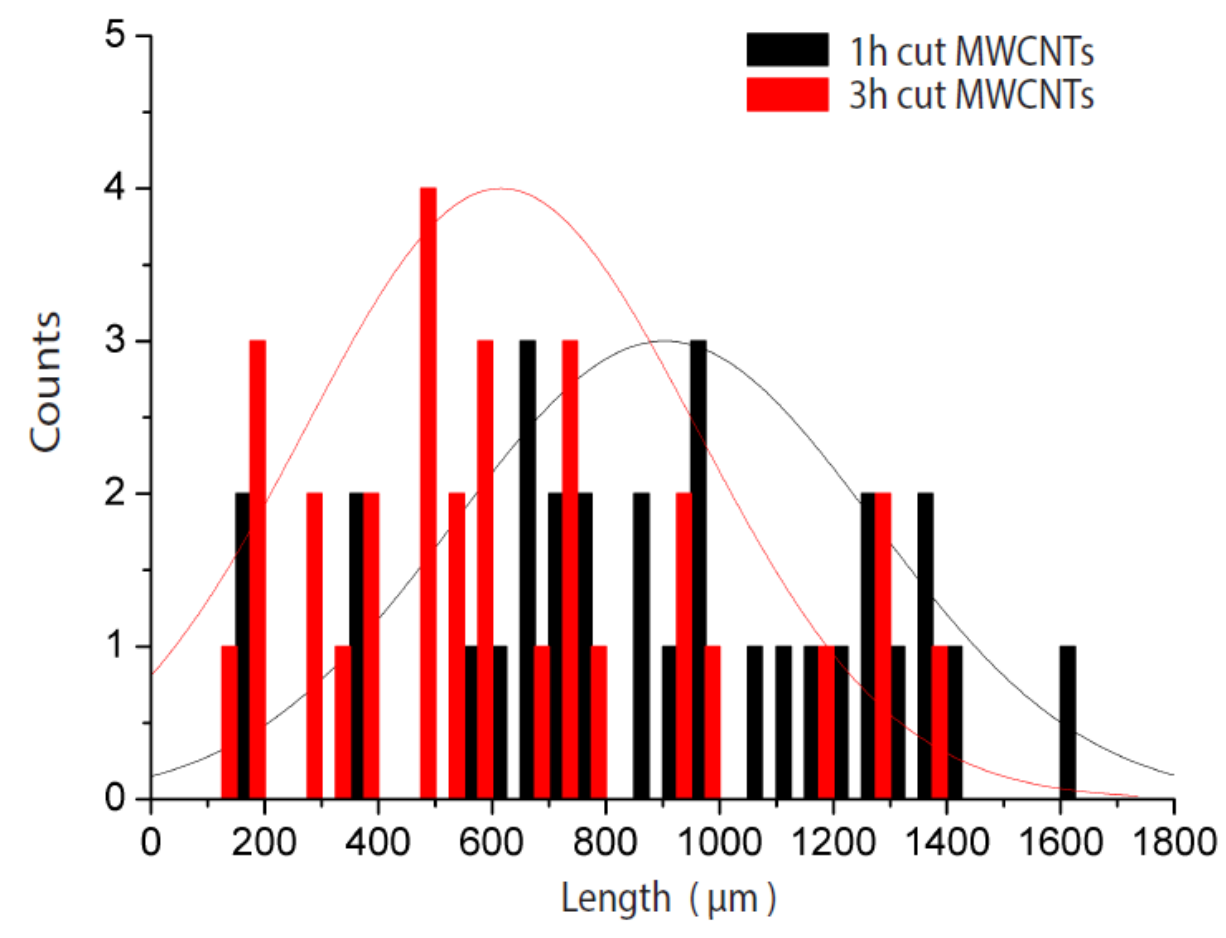

Figure 1A: Characterization of the multi-walled carbon nanotubes (MWCNTs). A) Histogram of Average Length distribution for (a) $1 \mathrm{~h}$ acids oxidized MWCNTs (black) $903 \pm 368$ $\mathrm{nm}$, and (b) $3 \mathrm{~h}$ acids oxidized MWCNTs (red) $616 \pm 344 \mathrm{~nm}$, identified by tapping mode Atomic Force Microscopy (AFM). 
Table 1: Raman spectra analyses of the 1 and $3 \mathrm{~h}$ acids oxidized MWCNTs.

Sample D band position $\left(\mathrm{cm}^{-1}\right) \quad G$ band position $\left(\mathrm{cm}^{-1}\right) \quad I_{D} / I_{G}$ Intensity ratio

1hr acid-treated

MWCNTs

1348

1585

0.788

$3 \mathrm{hr}$ acid-treated

MWCNTs

1349

1589

0.804

Table 2: Energy dispersive X-ray analyses of 1 and $3 \mathrm{~h}$ acid oxidized MWCNTs.

\begin{tabular}{ccc}
\hline Element \% & 1h cut MWCNTs & 3h cut MWCNTs \\
\hline $\mathrm{C}$ & 95.29 & 95.96 \\
$\mathrm{O}$ & 3.07 & 3.45 \\
$\mathrm{Fe}$ & 1.64 & 0.59
\end{tabular}

To determine the chemical properties of the acids oxidized MWCNTs, Raman and energy dispersive X-ray spectroscopy (EDX) analyses were performed. Raman spectrum of the 1 and 3 $\mathrm{h}$ acids oxidized MWCNTs are shown in Figure 1B while the peak characteristics are shown in Table 1. The D peak $\left(1350 \mathrm{~cm}^{-1}\right)$ relates to the presence of amorphous carbon on the MWCNTs sidewall and the $\mathrm{G}$ peak $\left(1590 \mathrm{~cm}^{-1}\right)$ is an indicator of high degree and well-structured crystal carbon based species. The two peaks were shifted towards higher frequencies for the $3 \mathrm{~h}$ acids oxidized MWCNTs when compared to $1 \mathrm{~h}$ sample. Further, the D and G peaks relative intensity ratio $I_{D} / I_{G}$, which indicates the degree of functionalization of the MWCNTs and is usually associated with the presence of free carboxyl acidic groups created at the nanotube wall interface, was 0.788 for $1 \mathrm{~h}$ and 0.804 for $3 \mathrm{~h}$ acids oxidized tubes respectively. This suggested that the increased number of carboxyl groups on the nanotube surface was proportional to longer 
acid treatment time ${ }^{92}$. The shifts in the additional peaks i.e. G' peak at $2670 \mathrm{~cm}^{-1}$ and a peak at $2920 \mathrm{~cm}^{-1}$ were associated with washing away the catalyst metal particles initially present in the pristine MWCNTs, thereby increasing electron-accepting groups. EDX analysis further confirmed that acid oxidation removed the metal catalysts leading to the carboxyl functional groups formation. The elemental compositions of the MWCNTs following 1 and $3 \mathrm{~h}$ oxidation are shown in Table 2. A decrease of the iron catalyst was observed for the $3 \mathrm{~h}$ acid oxidized sample when compared to the $1 \mathrm{~h}$ sample indicating that longer cutting times removed the catalyst to a larger extent. Furthermore, longer cutting times led to an increase of the oxygen content further confirming oxygen incorporation (i.e. formation of free carboxyl groups) on the nanotube side wall upon the longer oxidation time.

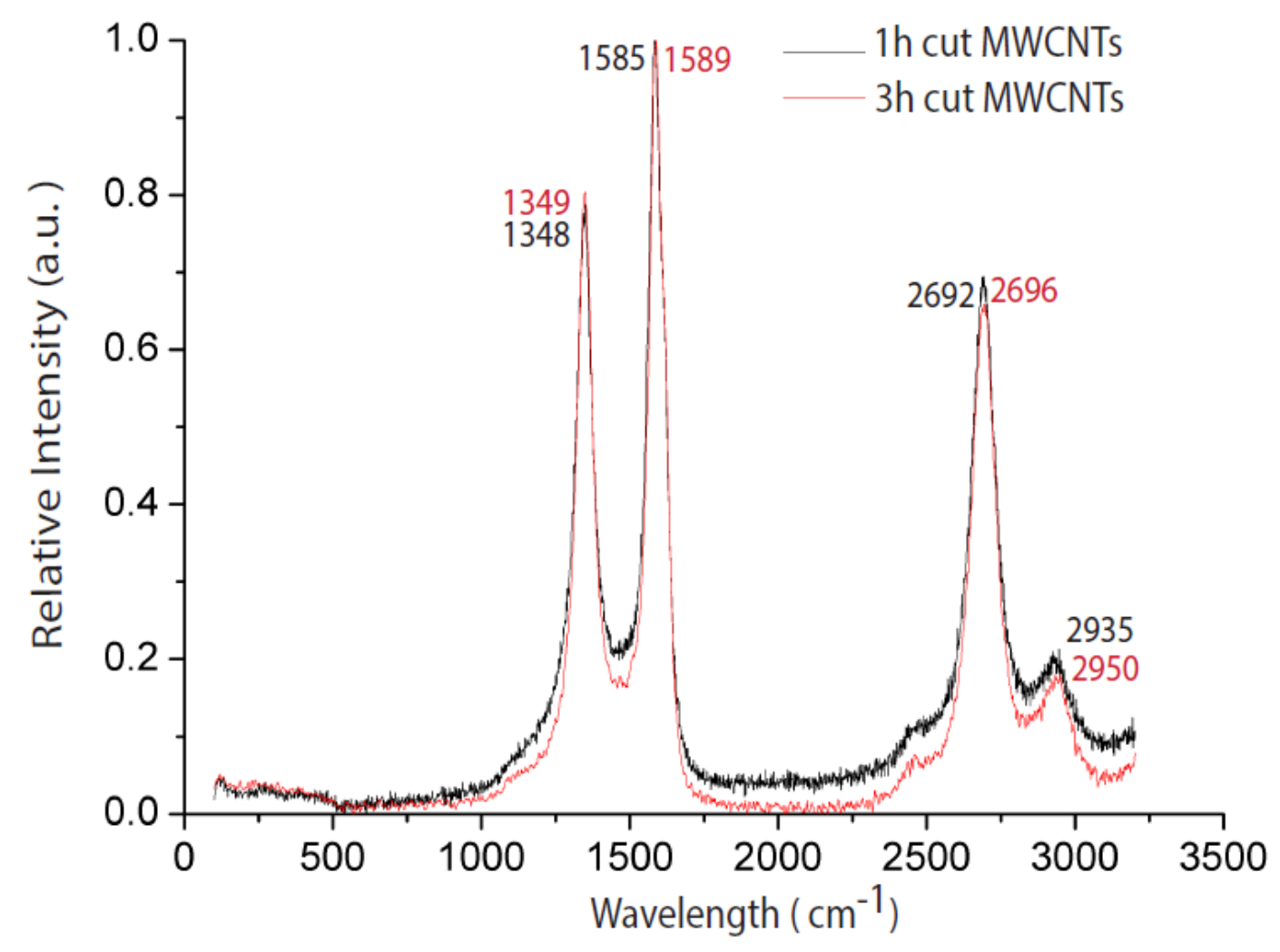

Figure 1B: Characterization of the multi-walled carbon nanotubes (MWCNTs). B) Raman Spectra of $1 \mathrm{~h}$ acids oxidized MWCNTs (black), and $3 \mathrm{~h}$ acids oxidized MWCNTs (red).

Dispersity of the 1 and $3 \mathrm{~h}$ acids oxidized samples was also evaluated. Highly dispersed nanotubes will ensure uniform treatment of the cellular systems and thus reduce permeability 
limitations while increase their net flux ${ }^{93}$ across the cell membrane. Our studies and others have shown that solubility of the MWCNTs samples can be attributed to the combined effects of generation of carboxylate anions derived by the de-protonation of surface reactive carboxylic groups and the stacking $\pi-\pi$ interactions between the MWCNTs surface and the amino acid ${ }^{94}$, and protein ${ }^{95}$ components in the cell culture media. Specifically, the dispersity of the MWCNTs samples (both 1 and $3 \mathrm{~h}$ acids oxidized) was evaluated in different dispersing agents (DI water (pH 6.25), PBS (pH 7) and DMEM including 10\% FBS and 1\% Anti/Anti media, or culture media). The results are shown in Figure 1C and indicated that the dispersity of the MWCNTs (both 1 and $3 \mathrm{~h}$ acids oxidized) in culture media was significantly improved when compared to the dispersity of the MWCNTs in the other agents. Further, the dispersity of the $3 \mathrm{~h}$ sample was higher than the one of the $1 \mathrm{~h}$ sample. The increase in solubility of MWCNTs samples after longer acids oxidation is correlated with the increase in the number of carboxylic acidic groups upon sample treatment as indicated both by the Raman and EDX analysis. The increased solubility observed for the MWCNT samples in PBS compared to Di water can be attributed to the greater de-protonation of the carboxyl acid groups at relative higher $\mathrm{pH}$ values ${ }^{96}$. 


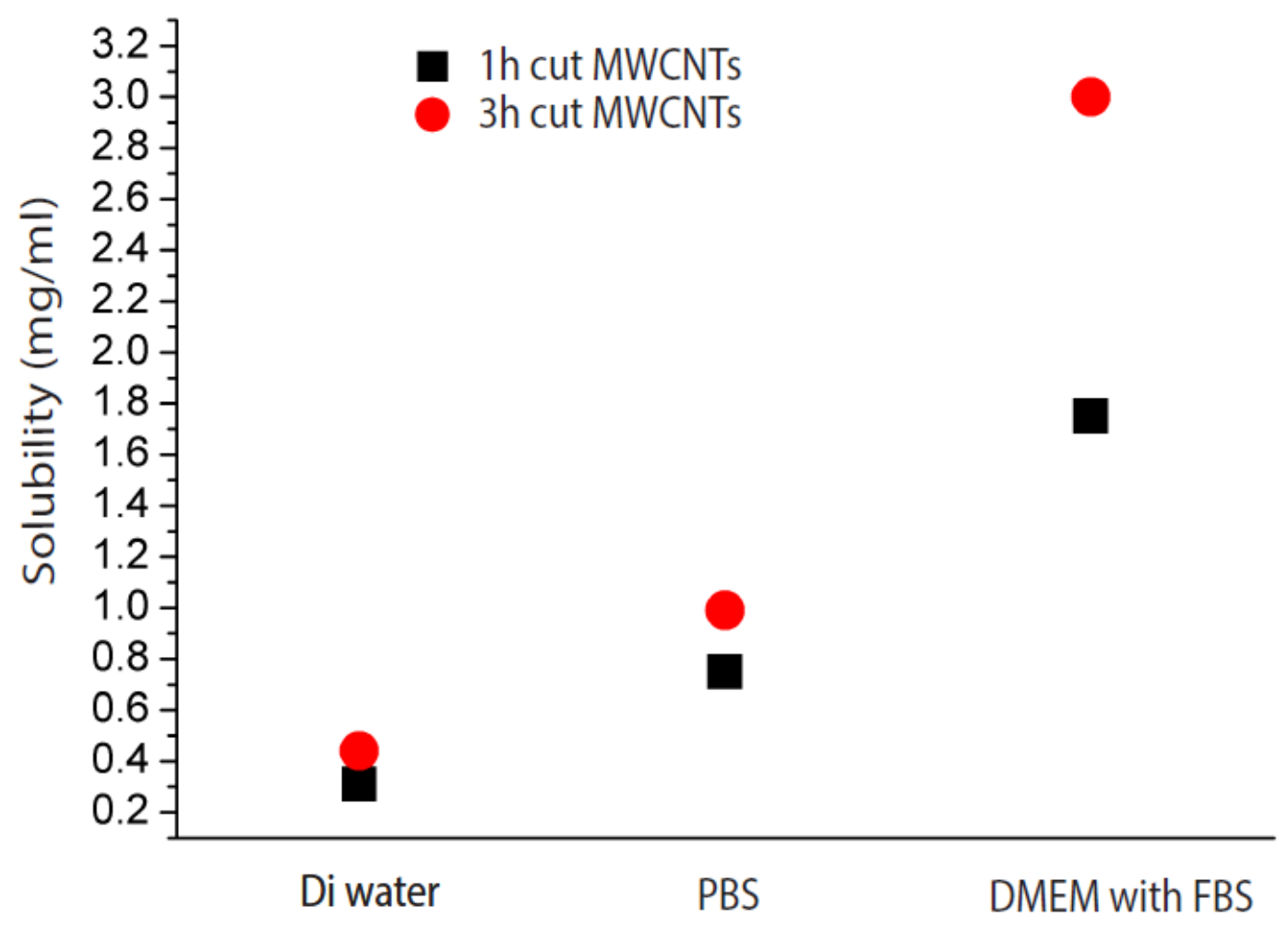

Figure 1C: Characterization of the multi-walled carbon nanotubes (MWCNTs). C) Dispersity of 1 and $3 \mathrm{~h}$ acids oxidized MWCNTs in water, PBS and media. The dispersity of $3 \mathrm{~h}$ was considerably improved relative with $1 \mathrm{~h}$ acids oxidized MWCNTs.

\section{Cell Cycle Analysis}

Physically and chemically characterized MWCNTs were used for treatment of immortalized human bronchial respiratory epithelial (BEAS-2B) cells (Figure 2A). Currently, occupational exposure guidelines indicated for nanomaterials (including MWCNTs) provide a recommended exposure limit (REL) of $7 \mu \mathrm{g} / \mathrm{m}^{397}$. Previous studies using in vitro models, used CNT dosages in excess, with impurities and defects ${ }^{18,48-51,98}$, and/or have been calculated assuming linearity from in vivo studies based on the surface area of the lung of the in vivo model organism ${ }^{9,10,99}$. In our studies, we treated cells with $0.24 \mu \mathrm{g} / \mathrm{mL}$ for $24 \mathrm{~h}$. This dosage was based on in vivo studies carried out at an exposure dosage of $20 \mu \mathrm{g} /$ mouse ${ }^{100}$, equivalent to $40 \mathrm{~h}$ of exposure for a 20 week duration at the OSHA particle exposure limit (PEL) of $5 \mathrm{mg} / \mathrm{m}^{3} 101$. $10,100,101$ 
A)
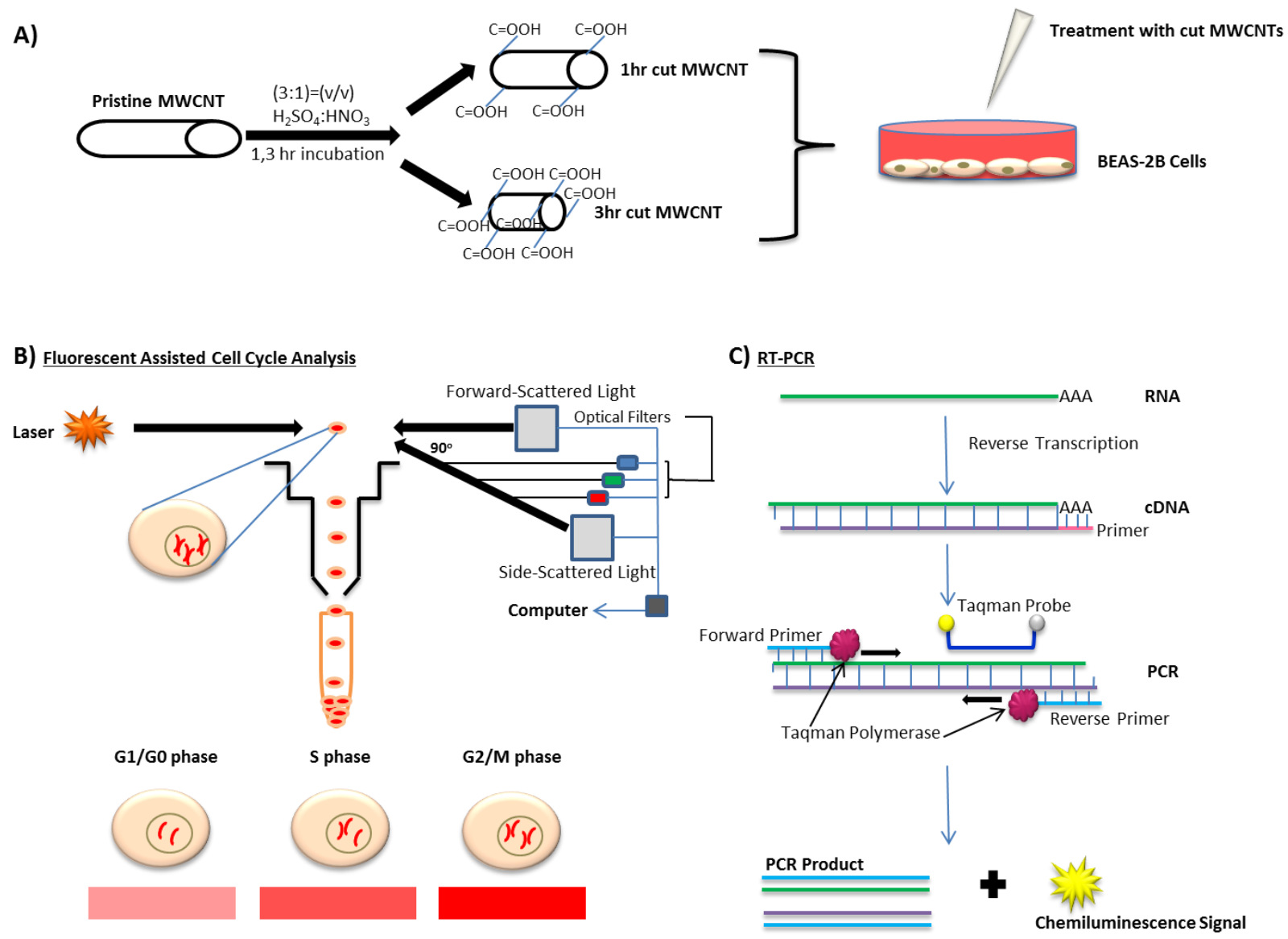

Figure 2: Cell Treatment and Analysis Summary Diagram: Procedural overview of the experiments: A) MWCNTs were acid-treated for 1 and $3 \mathrm{~h}$ and to lead to carboxyl functionalized nanotubes with different lengths and surface properties. Thus characterized MWCNTs are used to treat confluent BEAS-2B cells in culture dishes. B) Following cellular exposure to either 1 or $3 \mathrm{~h}$ acid oxidized MWCNTs for $24 \mathrm{~h}$, cells were stained with propidium iodide and subjected to cell cycle analysis by flow cytometry for finding of DNA content abnormalities. C) Following cellular exposure to either 1 or $3 \mathrm{~h}$ acid oxidized MWCNTs for $24 \mathrm{~h}$, real-time polymerase chain reactions (RT-PCR) was performed to identify any changes in the expression pathways of the key molecular players of the cell division. 
Table 3: Summary Table of Flow Cytometry Cell Cycle Analysis for G1 and S phases: The analysis shows that $3 \mathrm{~h}$ acids oxidized MWCNTs treatment resulted in significant changes (pvalue $<0.05)$ for both $\mathrm{G} 1$ and $\mathrm{S}$ phase, when compared to the changes induced by the $1 \mathrm{~h}$ acids oxidized MWCNT or the PBS controls.

\section{G1 Phase}

\begin{tabular}{llll}
\hline Treatment & \% Diploid Cells at $0 \mathrm{~h}$ & \% Diploid Cells at 24 h & \% Diploid Cells at 48hr \\
\hline PBS Control & 53.2 & 45.9 & 49.7 \\
1h acids oxidized MWCNTs & 54.9 & 39.7 & 42.9 \\
3h acid oxidized MWCNTs & 49.0 & 49.4 & $27.4 *$ \\
\hline
\end{tabular}

\section{S Phase}

\begin{tabular}{llll}
\hline Treatment & \% Diploid Cells at 0 & \% Diploid Cells at 24 h & \% Diploid Cells at 48hr \\
\hline PBS Control & 37.3 & 39.5 & 36.48 \\
1h acids oxidized MWCNTs & 35.4 & 46.7 & 48.5 \\
3h acids oxidized MWCNTs & 40.3 & 39.5 & $63.9 *$ \\
\hline
\end{tabular}

To address whether cell cycle was affected following cellular exposure to MWCNTs (either 1 or $3 \mathrm{~h}$ acids oxidized), fluorescent activated cell sorting (FACS) analyses was performed (Figure 2B). Previous studies have reported that the cell cycle arrests upon nanomaterial exposure due to direct interactions with both the mitotic spindle ${ }^{9,10}$, namely the cytoskeletal filament microtubule and with the DNA ${ }^{16,49}$. These interactions have been linked to cell proliferation blockage, mitotic spindle disturbances quantified by centrosome fragmentation ${ }^{16}$ and DNA clastogenic affects ${ }^{16}$. For our research, cells were incubated with MWCNTs for 24 $\mathrm{h}$, subsequently isolated at 0,24 and $48 \mathrm{~h}$ from culture and stained with propidium iodide for DNA labeling. Following isolation and staining, analyses were performed using the FACs Calibur and the data was normalized to 30,000 events.

The results are shown in Figure 3; the first peak (red) indicates cells in G1 phase, the second peak (blue) indicates cells in S phase and the third peak (green) indicates cells in G2 phase, respectively. Following exposure to $3 \mathrm{~h}$ acids oxidized MWCNTs cells moved out of G1 
phase into $\mathrm{S}$ phase, with no significant change in G2 phase when compared to the controls. Twoway ANOVA showed that there was a significant difference (p-value < 0.05) for both G1 and $\mathrm{S}$ phases in cells exposed to $3 \mathrm{~h}$ acids oxidized MWCNTs isolated at $48 \mathrm{~h}$ when compared to PBS controls or $1 \mathrm{~h}$ acids oxidized MWCNT treatment. Specifically, the $3 \mathrm{~h}$ acids oxidized MWCNTs treatment increased the percent of diploid cells in $\mathrm{S}$ phase to (mean $\%=63.9, \mathrm{p}<0.05$ ) when compared to PBS controls (mean $\%=36.48, \mathrm{p}>0.05$ ) and $1 \mathrm{~h}$ acids oxidized MWCNTs (mean $\%=48.5, \mathrm{p}>0.05$ ) treatment. For the cells in $\mathrm{G} 1$ phase the exact opposite was observed. The $3 \mathrm{~h}$ acids oxidized MWCNTs treatment decreased the percent of diploid cells to (mean $\%=$ $27.4, \mathrm{p}<0.05$ ) when compared to PBS control (mean \% $=49.7, \mathrm{p}>0.05$ ) and $1 \mathrm{~h}$ acids oxidized MWCNTs (mean $\%=42.9, \mathrm{p}>0.05$ ) treatment. Finally, neither treatment with 1 or $3 \mathrm{~h}$ acids oxidized MWCNTs affected cells in G2 phase when compared to the control PBS. The observed shift of the cells incubated with $3 \mathrm{~h}$ acids oxidized MWCNTs from G1 to $\mathrm{S}$ phase can be associated with an overall decrease in cellular division over time in response to the treatment ${ }^{9,10}$. The cell treated with $1 \mathrm{~h}$ acids oxidized MWCNTs did not show a significant loss of cell division over time in the same time frame when compared to the controls. 

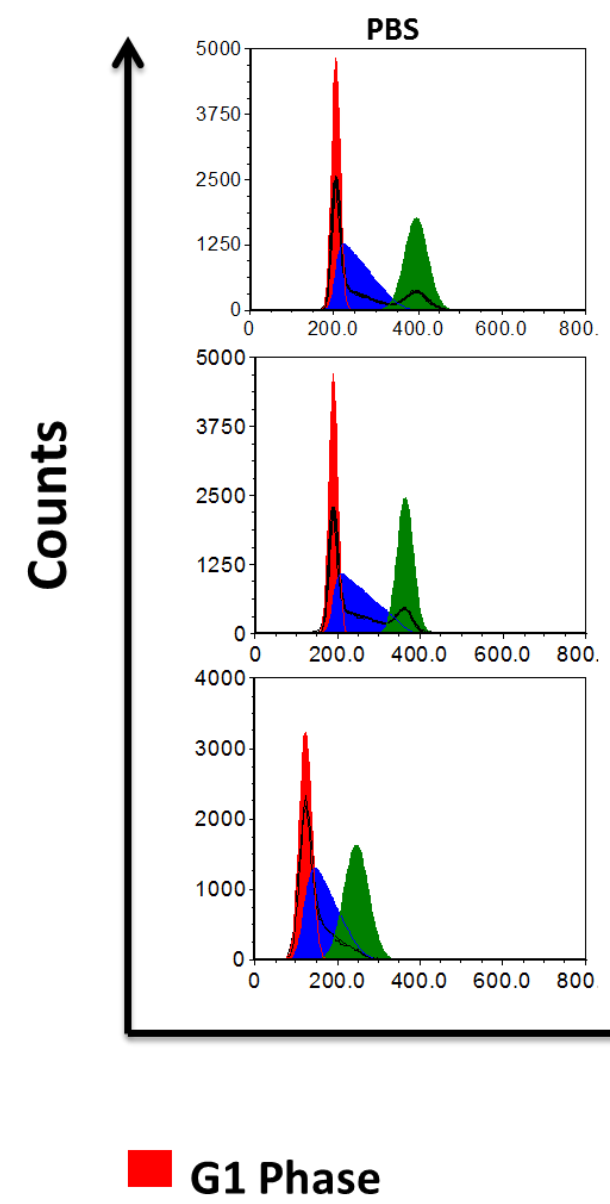
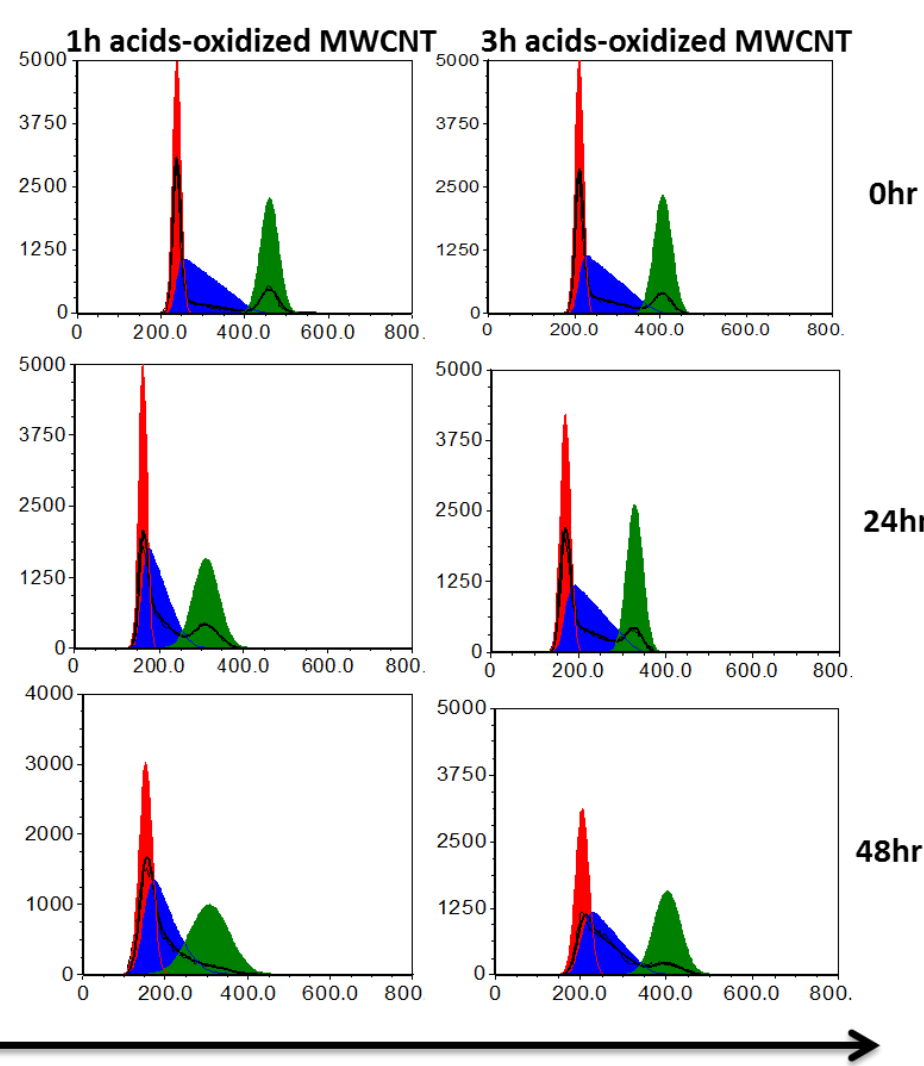

FL2-A

S Phase

\section{G2 Phase}

Figure 3: Graph of Flow Cytometry Cell Cycle Analysis: Cells stained with propidium iodide were read using the FACsCalibur flow cytometer, analyzed for their DNA content and sorted into G1(red), S (blue), or G2 (green) phase, timed isolation $(0,24,48 \mathrm{~h}$ ) and treatment (1 or $3 \mathrm{~h}$ acids-oxidized MWCNTs) respectively. For the $3 \mathrm{~h}$ acid-oxidized MWCNT group a clear decrease in G1 (red) phase and subsequent increase in S (blue) phase is shown for the $48 \mathrm{~h}$ time point as compared to the $1 \mathrm{~h}$ acid-oxidized MWCNT or PBS control groups.

\section{Dynein and Eg5 mRNA Expression}

Collective studies have shown that cell cycle arrest results in the destruction and expression of several regulatory proteins from down regulation of cyclin dependant kinases $(\mathrm{CDKs}){ }^{1}$ to up regulation of inhibitory p21 ${ }^{102}$ and p27 CDKs ${ }^{103}$. Further, studies have reported that interaction of CNTs with cellular elements, microtubules ${ }^{9}$, centrosomes ${ }^{10,16,18}$, and DNA $16,18,49$, and have resulted in changes in cellular elasticity ${ }^{104}$ that coordinated with changes in the 
cell cycle ${ }^{9,10}$, as an early indicator of tumorigenesis ${ }^{1}$. Based on these observations, we hypothesized that the observed cell cycle changes (Figure 3), could lead to changes in integral motor proteins associated within the cellular division process. In particular, we focused on two of the mitotic molecular motors, dynein and Eg5. Dynein is a minus end molecular motor that coordinates centrosome separation for successful bipolar spindle assembly ${ }^{61,66,68,75,76,105}$, while Eg5 is a plus end molecular motor that provides anti-parallel sliding forces necessary to evenly segregate genetic material into two daughter cells $53,56,57,77,82,106$. To address whether the integral mitotic molecular motor protein expression was affected upon cellular exposure to MWCNTs (both 1 and $3 \mathrm{~h}$ acids oxidized), RT-PCR was performed (Figure 2C). Briefly, RNA was isolated from cells treated with both 1 and $3 \mathrm{~h}$ acid oxidized MWCNTs and from control cells. High degree of RNA integrity was reversed transcribed into cDNA and RT-PCR was performed to quantify mRNA expression of the two molecular motors across $0,24,48$ and $72 \mathrm{~h}$.

The dynein and Eg5 mRNA expressions upon MWCNTs acids oxidized treatment are shown in Figure 4. Both dynein and Eg5 expressions were significantly (p-value < 0.05) reduced after $72 \mathrm{~h}$ post treatment when compared to controls. Interestingly however, the reduction in Eg5 expression in cells exposed to $3 \mathrm{~h}$ acids oxidized MWCNTs was observed after $48 \mathrm{~h}$ when compared to $1 \mathrm{~h}$ acids oxidized samples or control. Results shown in Figure 4 indicate that for dynein expression treatment with 1 or $3 \mathrm{~h}$ acids oxidized MWCNTs lead to roughly a 50\% reduction (arbitrary units) in mRNA expression at $72 \mathrm{~h}$, while for Eg5, treatment with 1 or $3 \mathrm{~h}$ acids-oxidized MWCNTs lead to roughly a 37.5\% reduction (arbitrary units) in mRNA expression at $72 \mathrm{~h}$ and roughly a 15\% reduction (arbitrary units) at $48 \mathrm{~h}$ for $3 \mathrm{~h}$ acids oxidized treatment only. 


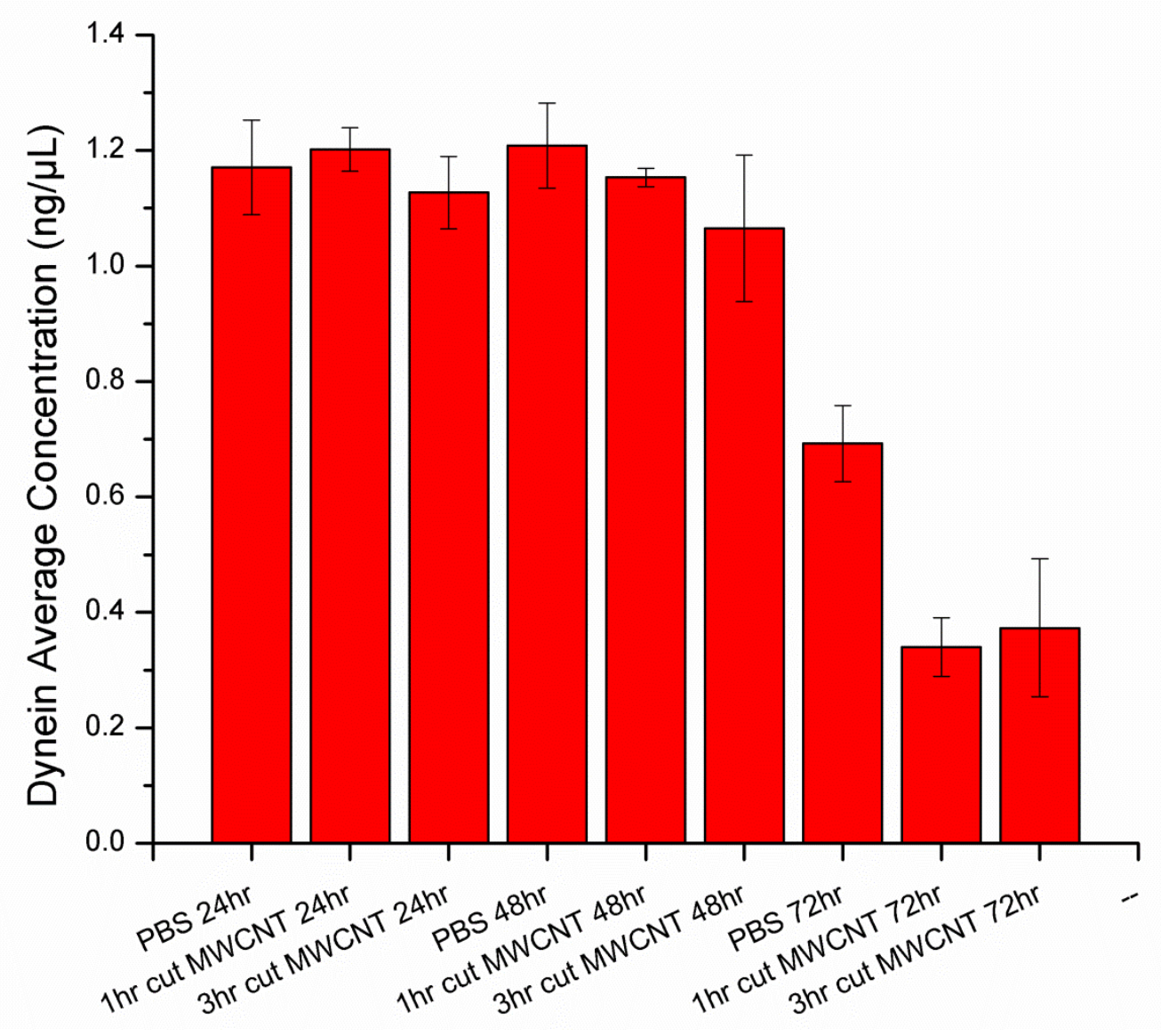

Figure 4A: Changes in expression levels of key proteins involved in the cell division. A) Graph of Dynein mRNA Expression: Cellular treatment for $24 \mathrm{~h}$ with both 1 and $3 \mathrm{~h}$ acids oxidized MWCNTs led to significant (p-value < 0.05) decreases in mRNA expression concentrations $(\mathrm{ng} / \mu \mathrm{L})$ as compared to PBS controls at $72 \mathrm{~h}$. 


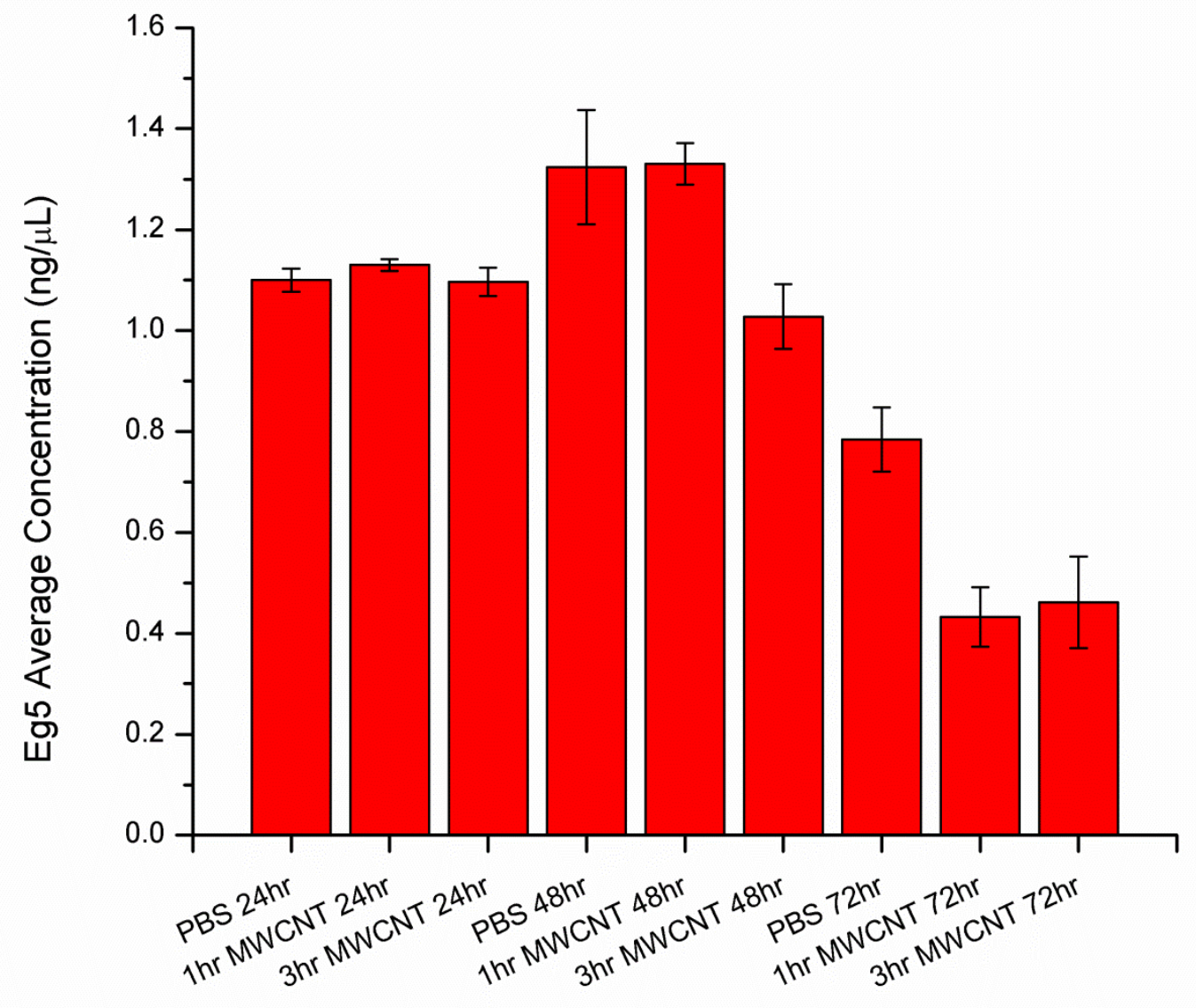

Figure 4B: Changes in expression levels of key proteins involved in the cell division. B) Graph of Eg5 mRNA Expression: Cellular treatment for $24 \mathrm{~h}$ with both 1and $3 \mathrm{~h}$ acids oxidized MWCNTs led to significant ( $\mathrm{p}$-value < 0.05) decreases in mRNA expression concentrations (ng/ $\mu \mathrm{L}$ ) as compared to PBS controls at $72 \mathrm{~h}$. Additionally treatment with $3 \mathrm{~h}$ acids oxidized MWCNTs led to significant ( $\mathrm{p}$-value < 0.05) decrease in mRNA expression concentrations $(\mathrm{ng} / \mu \mathrm{L})$ at $48 \mathrm{~h}$ when compared to $1 \mathrm{~h}$ acids treated MWCNTs and PBS controls.

\section{Discussion:}

Cell cycle consists of a comprehensive regulatory network of external and internal signals also influenced by environmental factors to coordinate cell division that ensures growth, differentiation and tissue formation ${ }^{6,107}$. As cells progress through their cell cycle, distinct 
proteins are being synthesized or degraded to ensure cycle-dependent turnover ${ }^{6,108}$. Such complex synthesis or degradation processes are dependent on distinct biochemical activities that take place inside the cells to ensure continuous regulation of RNA and protein levels maintenance ${ }^{6,109}$. Defects in the cell cycle as well as defects in the complex synthesis of the key protein players in cell cycle progression may lead to chromosome alterations, aneuploidy and ultimately cancer ${ }^{1,4}$. Our study aimed to evaluate the effects of acids oxidized MWCNTs treatment on the lung epithelial cell cycle and associated molecular motor proteins players in cell division.

We showed that the effects on the cell cycle were dependent on the MWCNTs properties (both chemical and physical). For instance, our results showed that following exposure for $24 \mathrm{~h}$ to $3 \mathrm{~h}$ acids oxidized MWCNTs, cells moved out of G1 phase (41\% decrease in G1 phase) and were subsequently arrested in the $\mathrm{S}$ phase $(33.5 \%$ increase in diploid cells in S phase) of the cell cycle at $48 \mathrm{~h}$, with no apparent changes observed for the $1 \mathrm{~h}$ acids oxidized MWCNTs in the same time interval relative to the control (not exposed cells). Additionally, we showed no observable \% change in diploid cells following either 1 or $3 \mathrm{~h}$ acids oxidized MWCNTs treatment at $24 \mathrm{~h}$, suggesting a maximal response time of $48 \mathrm{~h}$, also dependent on the MWCNTs properties (both chemical and physical). These findings are presumably an indicator of cell proliferation blockage ${ }^{9,10,17}$, with cells responding to treatment by arresting the cell cycle in an attempt to recover and/or repair cellular elements ${ }^{1}$ probably affected by exposure to MWCNTs and their physical and chemical properties. Our studies add to previous observations of cell cycle changes upon MWCNTs ${ }^{9}$ exposure. For instance, Zhang et al., have reported that treatment with carboxylated MWCNTs mediates over-expression of cyclin-dependant kinase inhibitor 1 (p21), a known inhibitor of CDK1 \& 2, independent of tumor protein 53 (p53) protein expression, via impaired bone morphogenic protein (BMP) signaling, suggesting that p21 alone, and not with p53 cooperation mediates cell cycle arrest in response to treatment with functionalized MWCNTs ${ }^{11,12}$. Further, Nam et al., found after treating normal rat kidney epithelial cells with sodium dodesoyl sulfate (SDS) functionalized SWCNTs a significant reduction in CDK2 and CDK6 cell cycle proteins, reduced phosphorylated-retinoblastoma (pRB) and lowered cell viability were observed, while at the same time p53 and p21 expression increased and growth arrest at the G0/G1 phase border was observed ${ }^{8}$. 
In the present investigations, we also quantified the levels of expression for dynein and Eg5, key molecular motors involved in the cellular division process, and how such levels were affected by exposure to acids oxidized MWCNTs. In particular, dynein and Eg5 mRNA concentrations were reduced in a time and MWCNT functionalization-dependent manner by 50 and $37.5 \%$ respectively, following exposure to both 1 and $3 \mathrm{~h}$ acids oxidized MWCNTs at $72 \mathrm{~h}$, when compared to the PBS control. Additionally, following treatment with $3 \mathrm{~h}$ acids oxidized MWCNTs only, Eg5 mRNA concentration was down-regulated by $15 \%$ at $48 \mathrm{~h}$. With respect to the differences recorded between exposure to 1 and $3 \mathrm{~h}$ acids oxidized MWCNTs, the distinct response in the cell cycle and protein expression could be attributed to the different characteristics of the MWCNTs. In particular, with an increase in the hydrophilicity and shorter nanotubes present at the cell incubation site, the ability of those nanotubes to be taken up and cross the biological barrier of the cell membrane is higher than for the longer and more hydrophobic nanotubes ${ }^{51,98,110-112}$.

Our results showed that following exposure for $24 \mathrm{~h}$ to $3 \mathrm{~h}$ acids oxidized MWCNTs, cells moved out of G1 phase (41\% decrease in G1 phase) and were subsequently arrested in the S phase (33.5\% increase in diploid cells in S phase) of the cell cycle at $48 \mathrm{~h}$. Based on previous studies it is expected that dynein is normally up-regulated in the $\mathrm{S}$ phase of the cell cycle, adding to centrosome duplication and centrosomal segregation ${ }^{62,69,74-76}$, and the organization of microtubule arrays ${ }^{54}$ of the mitotic spindle. However, no changes in the expression level of dynein where observed in our studies after $48 \mathrm{~h}$ exposure to acids-oxidized MWCNTs. Further, instead of an up-regulation of the motor upon $72 \mathrm{~h}$, the concentration of dynein was reduced to $50 \%$ when compared to the control. Similarly, Eg5 is normally up-regulated in late G2 phase and is required throughout the mitotic process $56,57,60,62,113$. However, our studies showed that there was a $15 \%$ at $48 \mathrm{~h}$ and a $37.5 \%$ at $72 \mathrm{~h}$ reduction following exposure to both 1 and $3 \mathrm{~h}$ acids oxidized MWCNTs, when compared to the PBS control. These are presumably due to the defects that exposure to MWCNTs introduced to the cellular cycle and the cell division apparatus. In particular, previous studies that shown that upon $24 \mathrm{~h}$ exposure of the cells to MWCNTs, nanotubes localize at the cell nucleus and they change the biomechanics of the cells ${ }^{104}$. MWCNTs could thus lead the reorganization of the cytoskeletal and disruption of the mitotic spindle ${ }^{114}$. Further, upon their integration with cellular microtubules, a biohybrid could be formed ${ }^{115}$ to induce errors in chromosome numbers ${ }^{116}$ and thus point to cell transformation in 
cancer cells $^{117}$. As the cells are being arrested in the pre- $\mathrm{G}_{2}$ phases of the cell cycle, the cell could not progress through a normal division process and thus through a normal cell cycle, to be able ensure the quality and the control associated with reliability in cellular DNA replication or in the maintenance of the cell cycle and responsible proteins involved with cell cycle progression. The DNA damage that could have resulted upon association with the MWCNTs $16,18,48,49,51,98$, as well as the defects in the spindle formation ${ }^{9}$ may modulate epithelial cell responses germane to genotoxic stress ${ }^{5}$, cell death ${ }^{6,7}$, or initiation of cancer ${ }^{1,4}$.

The combination of the cell cycle and molecular motors analyses might also suggest an overall destabilization of the mitotic spindle assembly as a result of treatment with MWCNTs (Figure 5). Generally, there has to be a subtle balance within the cell cycle between increasing molecular motor activity/concentration ${ }^{73}$, and the greater positive and negative cytoplasmic damping forces that act upon them ${ }^{73}$, while at the same time maintaining microtubule and spindle integrity ${ }^{54}$ relative to critical timings of the cell cycle (Figure 5A). Our data showed a disruption in the expression of these important mitotic players at times critical to their function that could presumably lead to abnormalities in the spindle assembly (Figure 5B). For instance, at $48 \mathrm{~h}$, a critical doubling time for BEAS-2B cells ${ }^{118}$ when Eg5 activity is required for spindle formation, cells treated with $3 \mathrm{~h}$ acids oxidized MWCNTs lack full expression of Eg5, i.e. a reduction of $15 \%$. Thus, the spatial relationship of opposing-forces generated between the mitotic molecular motor proteins, dynein and Eg5 will not be balanced to promote a normal spindle formation leading to monopolar spindle formation. Previous research showed that when an Eg5 small molecule inhibitor, monastrol was administered, or siRNA Eg5 expression knockdown occurred, cell cycle arrest ${ }^{57,60,62,119,120}$ and monopolar spindle formation ${ }^{62,119,120}$ resulted. Further, depending on when Eg5 is inhibited during the mitotic process, spindle assembly might not occur at all. Ferenz et al., have reported for instance that if centrosomes are $\leq 5.5 \mu \mathrm{m}$ apart, and microtubule arrays were not well established at the time Eg5 was inhibited, dynein was unable to functionally interact with the underdeveloped microtubule region, in an act to rescue centrosome separation and provide antiparallel sliding motion, hence resulting to monopolar spindles formation ${ }^{58}$. Additionally, this study suggested a novel role for dynein ${ }^{58}$, also supported by recent research that showed that spindle assembly requires the binding of the microtubule to the $\mathrm{p} 150$ subunit of dynactin ${ }^{121}$ at the CLIP-170 region where it then binds to dynein and antagonizes Eg5 movement ${ }^{69}$. 


\section{A Comparative Overview of Mitotic Spindle Formation}

A)
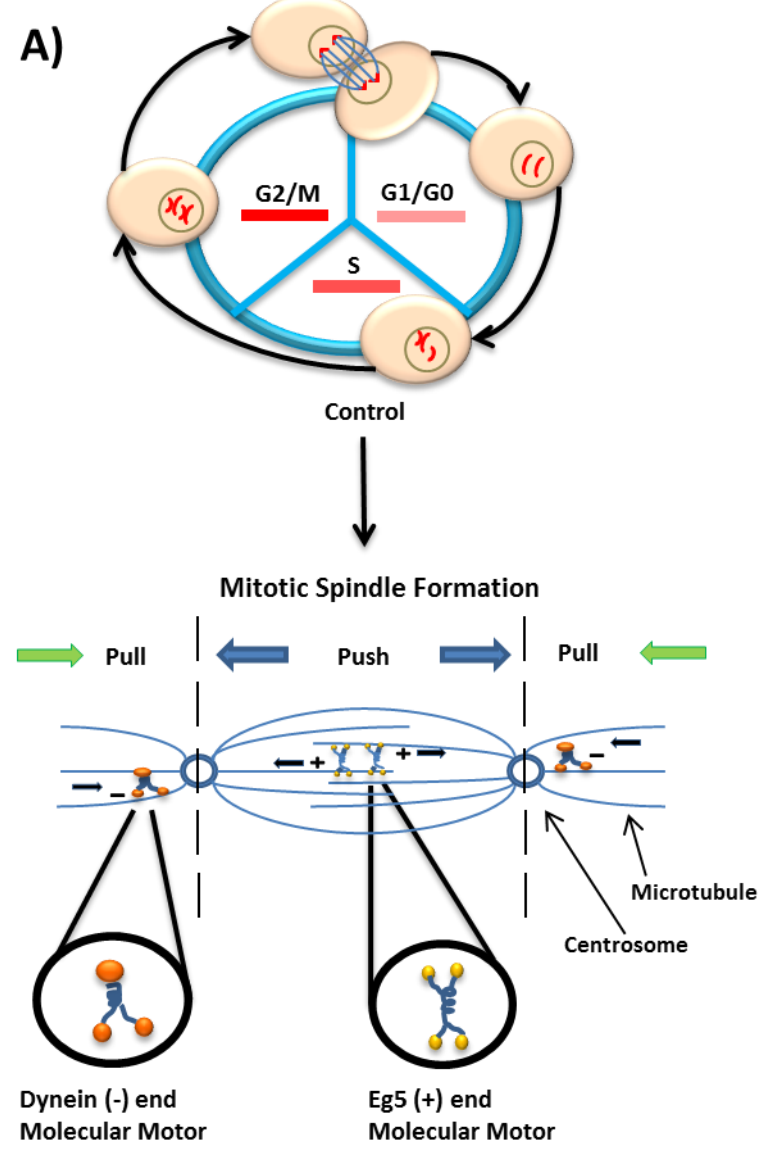

B)

Cells are sequestered in

$S$ phase at $48 \mathrm{hrs}$

following $3 \mathrm{hr}$ acidtreated MWCNT treatment.

Aberrations in Mitotic Spindle Formation

- Centrosome mis-segregation

- Monopolar spindle formation

- Unequal molecular motor force balances i.e. mitotic slippage, polyploidy ( $\geq 4 N$ )

Figure 5: Comparative Overview of Mitotic Spindle Formation-following treatment with MWCNTs the following aberrations are possible with respect to the mitotic spindle assembly relative to the abundance and control of integral mitotic molecular motors, Eg5 and Dynein.

Finally, expression and activity of these integral mitotic molecular motors are regulated through the cell cycle via check-point regulation of cyclin dependent kinases ${ }^{53,55,83,122,123}$, and of their respective promoter regions ${ }^{122,124}$. Thus, if critical timings of the cell cycle are affected by exposure to MWCNTs, reductions in mRNA expression of integral molecular motors will follow; our data support this assertion. Further, as studies have reported, MWCNTs have the ability to biopersists ${ }^{125}$, here the concern is that continued exposure could lead to a full 
dismantling of the mitotic apparatus, leading to mono and multipolar spindle formation ${ }^{9}$ through fragmentation of the centrosome and breakage of the DNA ${ }^{16,49}$. Ultimately, this continued cellular insult can result de-regulation ${ }^{4,126}$ of the cell cycle and initiation of aneuploidy ${ }^{127}$.

\section{$\underline{\text { Conclusion }}$}

In conclusion, the present investigations reveal that $24 \mathrm{~h}$ MWCNTs exposure ( 1 and $3 \mathrm{~h}$ acids oxidized, at $0.24 \mu \mathrm{g} / \mathrm{ml}$ ) induced changes in the BEAS-2B cell cycle. Further, our data is the first to show expressional changes in the integral molecular motor protein dynein and Eg5, key players of the cellular division process. The observed changes are dependent on the MWCNT physical and chemical properties. Disruption of the cell cycle and expression of motor proteins involved in the microtubule spindle formation and cellular division are an early indicator of the potential genotoxicity induced by the carbon nanotube, and MWCNTs-induced cancer progression. This investigation also provides useful information about the possible routes for aneuploidy while highlighting the need for further studies to address the role of cellular motors in the transport of nanomaterials as well as their possible role in tumorigenesis. 


\section{Reference}

1 Stewart ZA, W. M., Pietenpol JA. Cell-cycle dysregulation and anticancer therapy. Trends in Pharmacological Sciences 24, 139-145 (2003).

2 Weinberg, R. The Retinoblastoma Protein and Cell Cycle Control. Cell 81, 323-330 (1995).

3 Simon I, B. J., Hannett N, Harbison CT, Rinaldi NJ, et al. . Serial Regulation of transcriptional regulators in the yeast cell cycle Cell 106, 697-708 (2001).

4 Paulovich, A., Toczyski DP, Hartwell LH. When checkpoints fail. Cell 88, 315-321 (1997).

5 D'Assoro AB, B. R., Sunio K, Delva E, Almodovar-Mercado GJ, Johnson H, Folk C, Farrugia DJ, Vasile V, Strivala F, Salisbury JL Genotoxic stress leads to centrosome amplification in breast cancer cell lines that have inactive G1/S cell cycle checkpoint. Oncogene 23, 4068-4075 (2004).

6 Cooper, G. in The Eukaryotic Cell Cycle (Sinauer Associates, Sunderland (MA), 2000).

7 Schmidt KH, V. E., Harris LB, Mirzaei-Souderjani H, Syed S, Medicus R. Defects in DNA lesion bypass lead to spontaneous chromosomal rearrangements and increased cell death. Eurkaryot Cell 9, 315-324 (2010).

$8 \quad$ Nam CW, K. S., Kwak MK. Cell growth inhibition and apoptosis by SDS-solubilized single-walled carbon nanotubes in normal rat kidney epithelial cells. Arch Pharm Res 34, 661-669 (2011).

9 Rodriguez-Fernandez L, V. R., Gonzalez J, Villegas JC, Fanarraga ML. Multiwalled carbon nanotubes display microtubule biomemetic properties in vivo, enhancing microtubule assembly and stabilization. ACS Nano 6, 6614-6625 (2012).

10 Sargent LM, H. A., Young SH, Kashon ML, Dinu CZ, Salisbury JL, Benkovic SA, Lowry DT, Murray AR, Kisin ER, Siegrist KJ, Battelli L, Mastovich J, Sturgeon JL, Bunker KL, Shvedova AA, Reynolds SH. Single-walled carbon nanotube-induced mitotic disruption. Mutation Research 745, 28-37 (2012).

11 Tong L, Z. W., Hang H, Yu Z, Chu PK, Xu A. Toxicity of carbon nanotubes to p21 and hus1 gene deficient mammalian cells. J Nanosci Nanotechnol 11, 11001-11005 (2011).

12 Zhang Y, Y. B. Cell Cycle Regulation by Carboxylated Multiwalled Carbon Nanotubes through p53-Independant Induction of p21 under the Control of the BMP Signaling Pathway. Chem Res Toxicol 26, 1212-1221 (2012).

13 AshaRani PV, L. K. M. G., Hande MP, Valiyaveettil S. Cytotoxicity and genotoxicity of silver nanoparticles in human cells. ACS Nano 3, 279-290 (2009).

14 Jia X, L. B., Ye M, Liu H, Shi X. Silica induces cell cycle changes through PI-3K/AP-1 pathway in human embryo lung fibroblast cells. Cell Biochem Funct 28, 613-619 (2010).

15 Wu J, S. J., Xue Y. Involvement of JNK and P53 activation in G2/M cell cycle arrest and apoptosis induced by titanium dioxide nanoparticles in neuron cells. Toxicol Lett 199, 269-276 (2010).

16 Muller J, D. I., Hoet PH, Lombaert N, Thomassen L, Huaux F, Lison D, and KirshVolders M. Clastogenic and aneugenic effects of multi-walled carbon nanotubes in epithelial cells Carcinogenesis 29, 427-433 (2008).

17 Sargent LM, S. A., Hubbs AF, Salisbury JL, Benkovic SA, Kashon ML, Lowry DT, Murray AR, Kisin ER, Friend S, McKinstry KT, Battelli L, and Reynolds SH. Induction 
of Aneuploidy by Single-Walled Carbon Nanotubes Environmental and Molecular Mutagenesis 50, 708-717 (2009).

18 Kisin ER, M. A., Sargent LM, Lowry DT, Chirila M, Siegrist KJ, Schwegler-Berry D, Leonard S, Castranova V, Fadeel B, Kagan VE, and Shvedova AA. Genotoxicity of carbon nanofibers: Are they potentially more or less dangerous than carbon nanotubes or asbestos? Toxicology and Applied Pharmacology 252, 1-10 (2011).

19 Iijima, S. Helical microtubules of graphitic carbon. Nature 354, $56-58$ (1991).

20 Thostenson, E. T. Advances in the science and technology of carbon nanotubes and their composites: a review. Composities Science and Technology 61, 1899-1912 (2001).

21 Zhu HW, X. C., Wu DH, Wei BQ, Vajtai R, Ajayan PM. Direct synthesis of long singlewalled carbon nanotube strands. Science 296, 884-886, doi:10.1126/science.1066996 (2002).

22 Kelly, A. Composite Material after Seventy Years. J Mater Sci 41, 905-912 (2006).

23 Rohatgi, P. Cast aluminum-matrix composites for automotive applications. JOM 43, 1015 (1991).

24 Ruoff, R. Mechanical and thermal properties of carbon nanotubes. Carbon 33, 925-930 (1995).

25 Rawal, S. Metal-Matrix Composites for Space Applications. JOM 53, 14-17 (2001).

26 Shelly JS, L. R., Nichols J. Metal-Matrix Composites for Liquid Rocket Engines. JOM 53, 18-21 (2001).

27 Bachtold A, H. P., Nakanishi T, Dekker C. Logic Circuits with Carbon Nanotube Transistors. Science 294, 1317-1320 (2001).

28 Derycke V, M. R., Appenzeller J, Avouris P Carbon Nanotube Inter-and Intramolecular Logic Gates. Nano Lett 1, 453-456 (2001).

29 Fuhrer MS, K. B., Durkop T, Brintlinger. High-Mobility Nanotube Transistor Memory. Nano Lett 2, 755-759 (2002).

30 Hamada N., S., S., and Oshiyama A. New one-dimensional conductors: Graphitic microtubules. Phys. Rev. Lett. 68, 1579-1581 (1992).

31 Mintmire JW, D. B., and White CT. Are fullerene tubules metallic? Phys. Rev. Lett. 68, 631-634 (1992).

32 Saito R, F. M., Dresselhaus G, and Dresselhaus MS. Physical Properties of Carbon Nanotubes. Phys. Rev. B: Condens. Matter Mater Phys. 46, 1804-1811 (1992).

33 Steinhogl W, S. G., Stinelesberger G, Traving M, Engelhardt. Comprehensive study of the resistivity of copper wires with lateral dimensions of $100 \mathrm{~nm}$ and smaller. $J$ Appli Phys 97, doi:http://dx.doi.org/10.1063/1.1834982 (2005).

34 Cherukuri P, B. S., Litovsky SH, Weisman RB. Near-infared fluorescence microscopy of single-walled carbon nanotubes in phagocytic cells. J Am Chem Soc 126, 15638-15639 (2004).

35 Huh YM, J. Y., Song HT, Kim S, Choi JS, Lee JH, Yoon S, Kim KS, Shin JS, Suh JS. In vivo magnetic resonance detection of cancer by using multifunctional magnetic nanocrystals. J Am Chem Soc 127, 12387-12391 (2005).

36 Khandare JJ, J.-B. A., Satavalekar SD, Bhansali SG, Aher ND, Kharas F, Banerjee SS. PEG-conjugated highly dispersive multifunctional magnetic multi-walled carbon nanotubes for cellular imaging. Nanoscale 4, 837-844 (2012). 
37 Liao H, P. B., Sitharaman B, Wang Y. Applications of carbon nanotubes in biomedical studies. Biomedical Nanotechnology: Methods adn Protocols, Methods in Molecular Biology 726, 223-241 (2011).

38 Wu HC, C. X., Liu L, Zhao F, Zhao Y. Chemistry of Carbon Nanotubes in Biomedical Applications. Journal of Materials Chemistry 20, 1036-1052 (2010).

39 Ramachandran S, E. K., Bachand GD, Vogel V, Hess H. Selective loading of kinesinpowered molecular shuttles with protein cargo and its application to biosensing. Small 2, 330-334 (2006).

40 Taira S, D. Y., Hiratsuka Y, Uyeda TQ, Yumoto N, Kodaka M Loading and unloading of molecular cargo by DNA-conjugated microtubule. Biotechnol Bioeng 99, 734-739 (2008).

41 Yinghuai Z, P. A., Carpenter K, Maguire JA, Hosmane NS, Takagaki M. Substituted caborane-appended water soluable single-walled carbon nanotubes: New approach to boron neutron capture therapy drug delivery. J Am Chem Soc 127, 9875-9880 (2005).

42 Gao A, A. A., Trigg AD, Singh N, Fang C, Tung CH, Fan Y, Buddharaju KD, Kong J. Accumulation mode field-effect transistors for improved sensitivity in nanowire-based biosensors. Anal. Chem. 79, 3291-3297 (2007).

43 Kurkina T, V. A., Ahmad A, Kern K, Balasubramanian K. Label-Free Detection of Few Copies of DNA with Carbon Nanotube Impedance Biosensors. Angew Chem Int Ed 50, 3710-3714 (2011).

44 Pan D, C. J., Yao S, Tao W, Nie L. An Amperometric Glucose Biosensor Based on Glucose Oxidase Immobilized in Electropolymerized Poly(o-aminopheiol) and Carbon Nanotubes Composite Film on a Gold Electrode. Analytical Sciences 21, 367-371 (2005).

45 Dai, H. Carbon nanotubes: synthesis, integration, and properties Acc Chem Res 35, 1035 1047 (2002).

46 Smart SK, C. A., Lu GQ, Martin DJ. The biocompatibility of carbon nanotubes Carbon 44, 1034-1047 (2006).

47 Sargent LM, R. S., Castranova V. Potential pulmonary effects of engineered carbon nanotubes: in vitro genotoxic effects. Nanotoxicology 4, 396-408 (2010).

48 Cavallo D, F. C., Ursini CL, Casciardi S, Paba E, Ciervo A, Fresegna AM, Maiello R, Marcelloni AM, Buresti G, Tombolini F, Bellucci S, Iavicoli S. Multi-walled carbon nanotube induce cytotoxicity and genotoxicity in human lung epithelial cells. J Appl Toxicol 32, 454-464 (2011).

49 Lindberg HK, F. G., Suhonen S, Vippola M, Vanhala E, Catalan J, Savolainen K, Norppa $\mathrm{H}$. Genotoxicity of nanomaterials: DNA damage and micronuclei induced by carbon nanotubes and graphite nanofibers in human bronchila epithelial cells in vitro. Toxicol Lett 186, 166-173 (2009).

50 Pacurari M, Y. X., Zhao H, Ding M, Leonard SS, Schwegler-Berry D, Ducatman BS, Sbarra D, Hoover MD, Castranova V, Vallyathan V. Raw Single-Wall Carbon Nanotubes Induce Oxidative Stress and Activate MAPKs, AP-1, NF-kB, and Akt in Normal and Malignant Human Mesothelial Cells. Environmental Health Perspectives 116, 1211-1217 (2008).

51 Ursini CL, C. D., Fresegna AM, Ciervo A, Maiello R, Buresti G, Casciardi S, Tombolini F, Bellucci S, Iavicoli S. Comparative cyto-genotoxicity assessment of functionalized and pristine multiwalled carbon nanotubes on human lung epithelial cells. Toxicology In Vitro 26, 831-840 (2012). 
52 Ng CT, L. J., Bay BH, Yung LYL. Current Studies into the Genotoxic Effects of Nanomaterials. Journal of Nucleic Acids 2010, doi:doi:10.4061/2010/947859 (2010).

53 Blangy A, L. H., d'Herin P, Harper M, Kress M, Nigg EA. Phosphorylation by p34 ${ }^{\text {cdc2 }}$ Regulates Spindle Association of Human Eg5, a Kinesin-Related Motor Essential fo Bipolar Spindle Formation In Vivo. Cell 83, 1159-1169 (1995).

54 Burakov A, K. O., Semenovva I, Zhaparova O, Nadezdina E, Rodionov V. Cytoplasmic Dynein is Involved in the Retention of Microtubules at the Centrosome in Interphase. Traffic 9, 472-480 (2008).

55 Cahu J, O. A., Hentrich C, Schek H, Drinjakovic J, Zhang C, Doherty-Kirby A, Lajoie G, Surrey T. Phosphorylation by Cdk1 Increases the Binding of Eg5 to Microtubules In Vitro and in Xenopus Egg Extract Spindles. PLoS ONE 3, e3936 (2008).

56 Castillo A, M. H., Godfrey VL, Naeem R, Justice MJ. Overexpression of Eg5 Causes Genomic Instability and Tumore Formation in Mice. Cancer Res 67, 10138-10147 (2007).

57 Chen Y, C. J., Poon RYC. Inhibition of Eg5 Acts Synergistically with Checkpoint Abrogatin in Promotic Mitotic Catastrophe. Mol Cancer Res 10, 626-635 (2012).

58 Ferenz NP, P. R., Fagerstrom C, Mogilner A, Wadsworth P. Dynein Antagonizes Eg5 by Crosslinking and Sliding Antiparallel Microtubules Curr Biol 19, 1833-1838 (2009).

59 Gable A, Q. M., Titus H, Balchand S, Ferenz NP, Ma N, Collins ES, Fagerstron C, Ross JL, Yang G, Wadsworth P. Dynamic reorganization of Eg5 in the mammalian spindle throughout mitosis requires dynein and TPX2. Mol Biol Cell 23, 1254-1266 (2012).

60 Nakai R, I. S., Takahashi T, Tsujita T, Okamoto S, Takada C, Akasaka K, Ichikawa S, Ishida H, Kusaka H, Akinaga S, Murakata C, Honda S, Nitta M, Saya H, Yamashita Y. K858, a Novel Inhibitor of Mitotic Kinesin Eg5 and Antitumore Agent, Induces Cell Death in Cancer Cells. Cancer Res 69, 3901-3909 (2009).

61 Quintyne NJ, S. T. Distinct cell cycle-dependant roles for dynactin and dynein at centrosomes. Journal of Cell Biology 159, 245-254 (2002).

62 Raajimakers JA, v. H. R., Meaders JL, Geers EF, Fernandez-Garcia B, Medema RH, Tenebaum ME. Nuclear envelope-associated dynein drives prophase centrosome separation and enables Eg5-independent bipolar spindle formation. The EMBO Journal 31, 4179-4190 (2012).

63 Meyer RE, K. S., Obeso D, Straight PD, Winey M, Dawson DS. Mps1 and Ipl1/Aurora B act sequentially to correctly orient chromosomes on the meitic spindle of budding yeast. Science 339, 1071-1074, doi:10.1126/science.1232518 (2013).

64 Tanenbaum ME, M. R. Mechanisms of centrosome separation and bipolar spindle assembly. Dev Cell 19, 797-806 (2010).

65 Blangy A, A. L., Nigg EA. Phosphorylation by p34 ${ }^{\mathrm{cd} 2}$ Protein Kinase Regulates Binding of the Kinesin-related Motor HsEg5 to Dynactin Subunit $\mathrm{p} 150^{\text {Glued }}$. The Journal of Biological Chemistry 272, 19418-19424 (1997).

66 Cytrynbaum EN, S. P., Brust-Mascher I, Scholey JM, Mogilner A. Early spindle assembly in Drosophilia embryos: role of a force balance involving cytoskeletal dynamics and nuclear mechanics. Mol Biol Cell 16, 4967-4981 (2005).

67 Busson S, D. D., Moreau A, Dompierre J, and De Mey JR. Dynein and dynactin are localized to astral microtubules and at cortical sites in mitotic epithelial cells. Curr Biol 8, 541-544 (1998).

68 Dujardin DL, V. R. Dynein at the cortex. Curr Opin Cell Biol 14, 44-49 (2002). 
69 Tanenbaum ME, M. L., Galjart N, Medema RH. Dynein, Lis1 and CLIP-170 counteract Eg5-dependdant centrosome separation during bipolar spindle assembly EMBO J 27, 3235-3245 (2008).

70 Vallee RB, W. J., Varma D, Barnhart LE. Dynein: an ancient motor protein involved in multiple modes of transport. J Neurobiol 58, 189-200 (2004).

71 King, S. The dynein microtubule motor. Biochem Biophys Acta 1496, 60-75 (2000).

72 Kardon JR, a. V. R. Regulators of cytoplasmic dynein motor. Nat. Rev. Mol. Cell Biol. 10, 854-865 (2009).

73 Pecreaux J, R. J., Kruse K, Julicher F, Hyman AA, Grill SW, Howard J. Spindle oscillations during asymmetric cell division require a threshold number of active cortical force generators. Curr biol 16, 2111-2122 (2006).

74 Splinter D, T. M., Lindqvist A, Jaarsma D, Flotho A, Yu KL, Grigoriev I, Engelsma D, Haasdijk ED, Keijzer N, Demmers J, Fornerod M, Melchior F, Hoogenraad CC, Medema RA, Akhmanova A. Bicaudal D2, dynein and kinesin-1 associate with nuclear pore complexes and regulate centrosme and nuclear positioning during mitotic entry. PLoS ONE Biol 8, e1000350 (2010).

75 Salisbury, J. Breaking the ties that bind centriole numbers. Nat Cell Biol 10, 255-257 (2008).

76 Salisbury JL, D. A. A., Lingle WL. Centrosome amplification and the origin of chromosomal instability in breast cancer. J Mammary Gland Biol Neoplasia 9, 275-283 (2004).

77 Cole DG, S. W., Sheehan KB, Scholey JM. A "slow" homotetrameric kinesin-related motor protein purified from Drosophilia embryons. J Biol Chem 269, 22913-22916 (1994).

78 Kapitein LC, P. E., Kwok BH, Kim JH, Kapoor TM, Schmidt CF. The bipolar mitotic kinesin Eg5 moves on both microtubules that it crosslinks. Nature 435, 114-118 (2005).

79 Le Guellec R, P. J., Courturier A, Le Guellec K, Roghi C, Philippe M. Cloning by differential screening of a Xenopus cDNA that encodes a kinesin-related protein. $\mathrm{Mol}$ Cell Biol 11, 3395-3398 (1991).

80 Sharp DH, M. K., Brown HM, Matthies HJ, Walczak C, Vale RD, Mitchison TJ, Scholey JM. The bipolar kinesin, KLP61F cross-links microtubules within interpolar microtubule bundles of Drosophiliz embryonic mitotic spindles. J Cell Biol 144, 125-138 (1999).

81 Swain KE, L. K., Philippe M, Mitchison TJ. Mitotic spindle organization by a plus-enddirected microtubule motor. Nature 359, 540-543 (1992).

82 Lockart A, C. R. Kinetics and motility of the Eg5 microtubule motor. Biochemistry 35 (1996).

83 Chee MK, H. S. B-cyclin/CDKs Regulate Mitotic Spindle Assembly by Phosphorylating Kinesins-5 in Budding Yeast. PLoS Genetics 6, e1000935 (2010).

84 Muller J, D. M., Panin N, Rabolli V, Huaux F, Lison D. Absence of Carciongenic Response to Multiwalled Carbon Nanotubes in 2-Year Bioassay in the Peritoneal Cavity of the Rat. Toxicological Sciences 110, 442-448 (2009).

85 Muller J, H. F., Moreau N, Misson P, Heiler JF, Delos M, Arras M, Fonseca A, Nagy JB, Lison D. Respiratory toxicity of multi-walled carbon nanotubes Toxicol. Appl.

Pharmacol. 207, 221-231 (2005). 
86 Dong C, C. A., Eldawud R, Perhinschi G, Rojanasakul Y, Dinu CZ. Effects of acid treatment on structure, properties and biocompatibility of carbon nanotubes. Applied Surface Science 264, 261-268 (2013).

87 Dinu CZ, Z. G., Bale SS, Anand G, Reeder PJ, Sanford K, Whited G, Kane RS, Dordick JS. Enzyme-Based Nanoscale Composites for Use as Active Decontamination Surfaces. Advanced Functional Materials 20, 392-398 (2010).

88 Bulletin, T. S.-T. T. (Thermo Fisher Scientific NanoDrop products, Wilmington, Delaware USA).

89 Schroeder A, M. O., Stocker S, Salowsky R, Leiber M, Gassmann M, Lightfoot S, Menzel W, Granzow M, Ragg T. The RIN: and RNA integrity number for assigning integrity values to RNA measurements. BMC Molecular Biology 7, doi:doi:10.1186/1471-2199-7-3 (2006).

90 Murray EL, S. D. Assays for determining poly (A) tail length and the polarity of mRNA decay in mammalian cells. Methods Enzymol 448, 483-504 (2008).

91 Forrest, G. A. \& Alexander, A. J. A model for the dependence of carbon nanotube length on acid oxidation time. J Phys Chem C 111, 10792-10798 (2007).

92 Dong, C. B. et al. Effects of acid treatment on structure, properties and biocompatibility of carbon nanotubes. Appl Surf Sci 264, 261-268 (2013).

93 Atwell BJ, K. P., Turnbull CGN. in Plants in Action: Adaptation in Nature, Performance in Cultivation (ed Kriedemann PE Atwell BJ, Turnbull CGN, Eamus D, Bieleski RL, Farquhar G) Ch. 4, (Macmillan Education Australia Pty Ltd, 1999).

94 Yang, Z., Wang, Z., Tian, X., Xiu, P. \& Zhou, R. Amino acid analogues bind to carbon nanotube via pi-pi interactions: comparison of molecular mechanical and quantum mechanical calculations. J Chem Phys 136, 025103, doi:10.1063/1.3675486 (2012).

95 Ge, C. C. et al. Binding of blood proteins to carbon nanotubes reduces cytotoxicity. $P$ Natl Acad Sci USA 108, 16968-16973, doi:DOI 10.1073/pnas.1105270108 (2011).

96 Shieh, Y. T., Chen, J. Y., Twu, Y. K. \& Chen, W. J. The effect of pH and ionic strength on the dispersion of carbon nanotubes in poly(acrylic acid) solutions. Polym Int 61, 554559 (2012).

97 Nanofibers, N. C. I. B. O. E. t. C. N. a. (2010 draft).

98 Vittorio O, R. V., Cuschieri A. Influence of purity and surface oxidation on cytotoxicity of multiwalled carbon nanotubes with human neuroblastoma cells. Nanomedicine: Nanotechnology, Biology, and Medicine 5, 424-431 (2009).

99 Ding L, S. J., Zhang T, Elboudwarej O, Jiang H, Selegue JP, Cooke PA, Gray JW, Chen FF. Molecular Characterization of the Cytotoxic Mechanism of Multiwall Carbon Nanotubes and Nano-Onions on Human Skin Fibroblast. Nano Lett 5, 2448-2464 (2005).

100 Shvedova AA, K. E., Murray AR, Johnson VJ, Gorelik O, Arapalli S, Hubbs AF, Mercer RR, Keohavong P, Sussman N, Jin J, Stone S, Chen B, Deye G, Maynard A, Castranova $\mathrm{V}$, Baron PA, Kagan V. Inhalation versus aspiration of single walled carbon nanotubes in C57BL/6 mice: inflammation, fibrosis, oxidative stress and mutagenesis. Am J Physiol Lung Cell Mol Physiol 295, L552-565 (2008).

101 OSHA. Limits for Air Contaminates: Occupational Safety and Health Standards, . Occupational Safety and Health Administration (2006).

102 Robinson, I. Oncogenic functions of tumour suppressor p21 (Waf1/Cip1/Sdi1): association with cell senescence and tumour-promoting activities of stromal fibroblasts. Cancer Lett. 179, 1-14 (2002). 
103 Guan X, W. Y., Xie R, Chen L, Bai J, Lu J, Kuo MT. p27 (Kip1) as a prognostic factor in breast cancer: a systematic review and meta-analysis. J Cell Mol. Med. 14, 944-953 (2010).

104 Dong C, K. M., Lowry D, Dordick JS, Reynolds SH, Rojanasakul Y, Sargent LM, Dinu CZ Exposure to Carbon Nanotubes Leads to Changes in Cellular Biomechanics. Adv. Heathcare Mater. 2, 1-7 (2013).

105 Gonczy P, P. s., Kirkham M, Hyman AA. Cytoplasmic dynein is required for distinct aspects of MTOC positioning, including centrosome separation, in the one cell stage Caenorhabditis elegans embryo. J Cell Biol 147, 135-150 (1999).

106 Bartoli KM, J. J., Woolford JL, Saunders WS. Kinesin molecular motor Eg5 functions during polypeptide synthesis. Mol Biol Cell 22, 3420-3430 (2011).

107 Nigg, E. Cyclin-dependant protein kinases: key regulators of the eukaryotic cell cycle. Bioessays 17, 471-480 (1995).

108 Rosner M, S. K., Hengstschlager. Merging high-quality biochemical fractionation with refined flow cytometry approach to monitor nucleocytoplasmic protein expression throughout the unperturbed mammalian cell cycle. Nature Protocols 8, 602-626 (2013).

109 WC, M. Mechanism and regulation of eukaryotic protien synthesis. Microbiol Rev 56, 291-315 (1992).

110 Lindberg HK, F. G., Singh R, Suhonen S, Jarventaus H, Vanhala E, Catalan J, Farmer PB, Savolainen KM, Norppa H. Genotoxicity of short single-wall and multi-wall carbon in human bronchial epithelial and mesothelial cells in vitro. Toxicology, doi:http://dx.doi.org/10.1016/j.tox.2012.12.008 (2013).

111 Liu D, W. L., Wang Z, Cuschieri A. Different cellular response mechanisms contribute to the length-dependent cytotoxicity of multi-walled carbon nanotubes. Nanoscale Research Letters 7, 361-371 (2012).

112 Madani SY, T. A., Dwek M, Seifalian AM. Functionalization of single-walled carbon nanotubes and their binding to cancer cells. International Journal of Nanomedicine 7 , 905-914 (2012).

113 Uzbekov R, P. C., Arlot-Bonnemains Y. Cell Cycle Analysis and Synchroniztion of the Xenopus laevis XL2 Cell Line: Study of the Kinesin Related Protein XIEg5. Microscopy Research and Technique 45, 31-42 (1999).

114 Rodriguez-Fernandez, L., Valiente, R., Gonzalez, J., Villegas, J. C. \& Fanarraga, M. L. Multiwalled Carbon Nanotubes Display Microtubule Biomimetic Properties in Vivo, Enhancing Microtubule Assembly and Stabilization. Acs Nano 6, 6614-6625, doi:Doi 10.1021/Nn302222m (2012).

115 Dinu CZ, B. S., Zhu G, and Dordick JS. Tubulin Encapsulation of Carbon Nanotubes into Functional Hybrid Assemblies. Small x, 1-6 (2009).

116 Hubbs, A. F. et al. Nanotoxicology-A Pathologist's Perspective. Toxicol Pathol 39, 301324, doi:Doi 10.1177/0192623310390705 (2011).

117 Silkworth, W. T., Nardi, I. K., Scholl, L. M. \& Cimini, D. Multipolar Spindle Pole Coalescence Is a Major Source of Kinetochore Mis-Attachment and Chromosome MisSegregation in Cancer Cells. Plos One 4, Doi 10.1371/Journal.Pone.0006564 (2009).

118 Hornberg C, M. L., Seemayer NH. Human bronchoepithelial cells in vitro as a tool for detection of genotoxic activity of airborne particulates. Journal of Aerosol Science 27, 35-36 (1996). 
119 Whitehead CM, R. J. Expanding the role of HsEg5 within the mitotic and post mitotic phases of the cell cycle. J. Cell. Sci. 444, 2551-2561 (1998).

120 Kapoor TM, M. T., Couglin ML, Mitchison TJ. Probing spindle assembly mechanisms with monastrol, a small molecule inhibitor of the mitotic kinesin, Eg5. J. Cell. Biol. 150, 975-988 (2000).

121 Kim H, L. S., Rogers GC, Kural C, Selvin PR, Rogers SL, Gelfand VI. Microtubule binding by dynactin is required for microtubule oranization but not cargo transport. $J$ Cell Biol 176, 641-651 (2007).

122 Nakano, H., Funasaka T, Hashizume C, Wong RW. Nucleoporin Translocated Promotor Region (Tpr) Associates with Dynein Complex, Preventing Chromosome Lagging Formation during Mitosis. J Biol Chem 285, 10841-10849 (2010).

123 Emre D, T. R., Poncet A, Rahmani Z, Karess RE. A mitotic role for Mad 1 beyond the spindle checkpoint. Journal of Cell Science 124, 1664-1671 (2011).

124 Liu M, A. R., Xiadong S, Xie S, Wang H, Wu X, Dong JT, Li M, Joshi H, Zhou J. Parkin Regulates Eg5 Expression by Hsp70 Ubiquitination-dependant Inactivation of c-Jun NH2-terminal Kinase. Journal of Biological Chemistry 283, 35783-35788 (2008).

125 Mercer RR, H. A., Scabilloni JF, Wang L, Battelli LA, Schwegler-Berry D, Castranova, Porter DW. Distribution and persistence of pleural penetrations by multi-walled carbon nanotubes. Particle and Fibre Toxicology 7, 1-11 (2010).

126 Stewart ZA, P. J. Cell Cycle Checkpoints as Therapeutic Targets. Journal of Mammary Gland Biology and Neoplasia 4, 389 (1999).

127 Jain S, S. S., Pillai S. Toxicity Issues Related to Biomedical Applications of Carbon Nanotubes. J Nanobed Nanotechol 3, 1000140 (2012). 